\title{
Life histories and seasonal dynamics of common boreal pelagic copepods (Crustacea, Copepoda) inhabiting an oligotrophic Fennoscandian lake
}

\author{
Svein Birger WÆRVÅGEN* and Jens Petter NILSSEN ${ }^{1)}$ \\ Hedmark University College, Department of Natural Sciences and Technology, N - 2306 Hamar, Norway \\ ${ }^{1)}$ University of Oslo, Natural History Museum, Department of Technical and Scientific Conservation, P.O. Box 1172 Blindern, N - \\ 0318 Oslo, Norway \\ *e-mail corresponding author: svein.warvagen@hihm.no
}

\begin{abstract}
The annual seasonal abundance and spatial distribution of four widespread pelagic copepods, the Palaeartic calanoid Eudiaptomus gracilis, the cyclopoids Mesocyclops leuckarti and Thermocyclops oithonoides, and the Holartic Cyclops scutifer were investigated in Lake Gjerstadvann, an oligotrophic boreal lake. Important ecological traits such as life cycles, pelagic microhabitats and wintering strategies varied strongly between the investigated copepods, and influenced seasonal succession in the plankton community. Fish predation did not seem to affect copepod abundances, except perhaps the two lage-sized, less abundant species, the Palaeartic calanoid Heterocope saliens and the Holartic cyclopoid Cyclops abyssorum. Life cycles varied from one (C. scutifer) to three (M. leuckarti and E. gracilis) complete generations per year, primarily related to habitat temperatures. Wintering took place as late instars (C. scutifer, C. abyssorum) or cop V and adults (E. gracilis) in the plankton, late instars in profundal (T. oithonoides) or littoral (M. leuckarti) sediment diapause, and embryonic diapause in sediment egg bank (H. saliens). C. scutifer and C. abyssorum exhibited delayed development in the profundal waters during winter, which could be characterised as so-called "active diapause". C. scutifer, T. oithonoides, and C. abyssorum in Lake Gjerstadvann were probably negatively affected by acidified waters. M. leuckarti seemed to be the most acid-tolerant of these species being able to endure pH slightly below 5.0, whereas T. oithonoides was usually absent at such pH levels. The calanoid species $\mathrm{H}$. saliens and E. gracilis were extremely tolerant towards acidic environments. The yearly differences in population abundance as indicated by the fluctuations in the diapausing populations were probably due to environmental variations in water chemistry occurring during the most vulnerable ontogenetic stages, i.e., eggs and nauplii. Even if the pelagic ecosystem in boreal and oligotrophic lakes may appear homogeneous, a whole array of life histories and dormancy patterns has evolved among copepods.
\end{abstract}

Key words: Copepoda, boreal lake, Eudiaptomus gracilis, Cyclops scutifer, Mesocyclops leuckarti, Thermocyclops oithonoides, life cycle, diapause, clutch size

\section{INTRODUCTION}

The boreal forest, or taiga, forms a distinctive biome which covers approximately 17 percent of the earth's land surface. The boreal ecosystem is characterized by numerous lakes (Schindler 1998), which cover approximately 10 percent of the boreal area (Molot \& Dillon 1996). Since many lakes are situated in remote areas, they are frequently low productive. Oligotrophic ecosystems and lakes are generally characterised by limited food availability, and most species of microcrustaceans suffer sub-optimal food conditions during most of the year (e.g., Conover 1968; Romanovsky 1985). However, boreal oligotrophic lakes influenced by humus, receive additional food through the catchment's production of organic material (Hessen \& Tranvik 1998; Keskitalo \& Eloranta 1999). Such food items show maximal abundance at predictable periods of the year, mainly during spring, summer and autumn rainfalls. The total assimilated energy for most organisms is nevertheless considerably less than in nutrient-rich environments.
Species characteristic of boreal, oligotrophic lakes are usually slow growing (e.g., Elgmork 1965, 2006). Body size differences are related to available food and habitat temperatures, and some size classes are eliminated by size selective predators. Visual predators, such as fish, remove the largest sized individuals, whereas invertebrate predators remove the smallest sized individuals (Stenson 1979; Zaret 1980). Pelagic copepods are among the most conspicuous inhabitants of inland waters in the boreal region (e.g., Elgmork 2006), and their life histories and seasonal distribution have been subject to detailed studies during the last decades (Elgmork 1962, 2004, 2006; Elgmork \& Nilssen 1978; Sarvala 1979; Elgmork \& Halvorsen 1998). Most freshwater copepods are omnivorous from the late larval instars to the adult stage. The nauplii and early copepodids usually consume phytoplankton and detrital food. The cyclopoid group and the larger-sized calanoids are most strongly carnivorous, whereas the smaller-sized species of both groups are able to mature with an herbivorous diet (Dussart \& Defaye 2001). 
Tab. 1. Sampling depths where chemical and quantitative zooplankton samples were collected (A) and (B) mean values of water chemical parameters in Lake Gjerstadvann 1980/81. Total organic material as $\mathrm{KMnO}_{4}$-demand; water colour as Pt; RAl: reactive aluminium; ANC: acid neutralizing capacity; specific conductivity as $\mathrm{K}_{25} ; \mathrm{T}=$ total.

(A)

\begin{tabular}{cccc}
\hline $\begin{array}{c}\text { Sample depths } \\
(\mathrm{m})\end{array}$ & $\begin{array}{c}\text { Representative layer } \\
(\mathrm{m})\end{array}$ & $\begin{array}{c}\text { Proportion } \\
(\%)\end{array}$ & $\begin{array}{c}\text { of total volume } \\
\left(\mathrm{m}^{3} \times 10^{6}\right)\end{array}$ \\
\hline 1 & $0-2$ & 13 & 1.83 \\
3 & $2-4$ & 12 & 1.68 \\
5 & $4-6$ & 10 & 1.52 \\
7 & $6-8$ & 10 & 1.42 \\
10 & $9-12$ & 17 & 2.54 \\
15 & $12-18$ & 22 & 3.15 \\
20 & $18-22$ & 10 & 1.52 \\
25 & $22-27$ & 6 & 0.88 \\
Mean depth: $15.3 \mathrm{~m}$ & Max. depth: $\mathrm{z}_{\mathrm{m}}=27 \mathrm{~m}$ & & Total volume: $14.54 \times 10^{6} \mathrm{~m}^{3}$ \\
\hline
\end{tabular}

(B)

\begin{tabular}{|c|c|c|c|c|c|c|c|c|c|}
\hline $\begin{array}{l}\text { Parameter } \\
\text { units }\end{array}$ & $\mathrm{pH}$ & $\begin{array}{c}\mathrm{KMnO}_{4} \\
\left(\mathrm{mg} \mathrm{O}_{2} \mathrm{~L}^{-1}\right)\end{array}$ & $\begin{array}{c}\mathrm{Pt} \\
\left(\mathrm{mg} \mathrm{L}^{-1}\right)\end{array}$ & $\begin{array}{c}\mathrm{Ca}^{2+} \\
\left(\mathrm{mg} \mathrm{L}^{-1}\right)\end{array}$ & $\begin{array}{c}\mathrm{Mg}^{2+} \\
\left(\mathrm{mg} \mathrm{L}^{-1}\right)\end{array}$ & $\begin{array}{c}\mathrm{Na}^{+} \\
\left(\mathrm{mg} \mathrm{L}^{-1}\right)\end{array}$ & $\begin{array}{c}\mathrm{K}^{+} \\
\left(\mathrm{mg} \mathrm{L}^{-1}\right)\end{array}$ & $\begin{array}{c}\mathrm{TFe} \\
\left(\mathrm{mg} \mathrm{L}^{-1}\right)\end{array}$ & $\begin{array}{c}\mathrm{TMn} \\
\left(\mathrm{mg} \mathrm{L}^{-1}\right)\end{array}$ \\
\hline Annual means & 5.2 & 5 & 20 & 1.9 & 0.38 & 1.2 & 0.46 & 0.32 & 0.06 \\
\hline $\begin{array}{l}\text { Parameter } \\
\text { units }\end{array}$ & $\begin{array}{c}\mathrm{SO}_{4}{ }^{2-} \\
\left(\mathrm{mg} \mathrm{L}^{-1}\right)\end{array}$ & $\begin{array}{c}\mathrm{Cl}^{-} \\
\left(\mathrm{mg} \mathrm{L}^{-1}\right)\end{array}$ & $\begin{array}{c}\mathrm{SiO}_{2} \\
\left(\mathrm{mg} \mathrm{L}^{-1}\right)\end{array}$ & $\begin{array}{c}\mathrm{RAl} \\
\left(\mathrm{mg} \mathrm{L}^{-1}\right)\end{array}$ & $\begin{array}{c}\mathrm{NO}_{3}^{-} \\
\left(\mathrm{mg} \mathrm{L}^{-1}\right)\end{array}$ & $\begin{array}{c}\mathrm{NH}_{4}^{+} \\
\left(\mathrm{mg} \mathrm{L}^{-1}\right)\end{array}$ & $\begin{array}{c}\mathrm{TP} \\
\left(\mu \mathrm{g} \mathrm{L}^{-1}\right)\end{array}$ & $\underset{\left(\mu \mathrm{ekv} \mathrm{L}{ }^{-1}\right)}{\mathrm{ANC}}$ & $\begin{array}{c}\mathrm{K}_{25} \\
\left(\mathrm{mS} \mathrm{m}^{-1}\right)\end{array}$ \\
\hline Annual means & 6.3 & 2.2 & 0.34 & 0.23 & 0.22 & 0.11 & 8 & -6.7 & 2.7 \\
\hline
\end{tabular}

Life cycles of many copepods are synchronised with predictable seasonal variations in their environments (e.g., Nilssen 1980a). Potential advantages of this welldocumented phenomenon include the avoidance of physiological stressful or intolerable conditions such as transient anoxia, natural enemies, negative energy balance, all subsequently influencing fecundity and offspring viability. Life histories exhibiting such synchrony are most often associated with a diapause or dormancy phase (Elgmork 1959; Alekseev et al. 2007).

The oligotrophic, acidified Lake Gjerstadvann is situated in boreal southern Norway, in an area where aquatic ecosystems have been studied since the early 1970s. Pelagic copepods in this region have been surveyed in a variety of lakes subject to conflicting predation pressures from invertebrates to fish, which collectively act to produce a diversity of copepod life histories. The copepods studied are the most common pelagic species in the western part of the Eurasian boreal region (Illies 1978; Kiefer 1978), and include Eudiaptomus gracilis, Cyclops scutifer, Mesocyclops leuckarti, Thermocyclops oithonoides, Cyclops abyssorum, and Heterocope saliens.

The boreal copepods listed above, all inhabited the pelagial of Lake Gjerstadvann, an apparently homogeneous environment exhibiting low production. The aim of this study was to examine the pelagic copepods in an oligotrophic, boreal lake, with special emphasize on pelagic development, pelagic-benthic coupling and diapause development. It encompasses life-cycle patterns, including wintering strategies, dormancy or resting habitats, pattern and type of diapause, seasonal micro- habitat distribution of all ontogenetic stages, reproductive patterns, and susceptibility to fish and possibly invertebrate predators. With such data available, we aimed to identify major ecological factors behind the different life histories and habitat distributions.

\section{METHODS}

\subsection{Abiotic and biotic environment}

Chemical samples were collected using a Ruttner sampler at a fixed station at the deepest point $(27 \mathrm{~m})$ of the lake (Fig. 1b), at depths shown in table 1a. Chemical and biological samples were taken simultaneously every fortnight during the ice-free period, and about monthly the rest of the year from primo February 1980 to medio March 1981 (sediment samples were also collected in 1982, 1983, and 1985). Chemical analyses were performed according to standard analytical methods, and parameters are shown in table 1B. $\mathrm{pH}$ was measured electrometrically (Radiometer PHM 82) with a glass electrode. Metals such as $\mathrm{Ca}^{2+}, \mathrm{Na}^{+}, \mathrm{TFe}$ were analysed with a flame AAS (Perkin-Elmer 603). Reactive aluminium (RAl), $\mathrm{NH}_{4}{ }^{+}$, total phosphorous (TP), $\mathrm{SiO}_{2}$ and water colour (primarily allochthonous organic matter as mg Pt L ${ }^{-1}$ ) were measured with a Cecil Instruments spectrophotometer (Ce 393). $\mathrm{KMnO}_{4}$-demand was determined by titration according to standard analytical methods. Analysis of $\mathrm{SO}_{4}^{2-}, \mathrm{Cl}^{-}$and $\mathrm{NO}_{3}^{-}$were performed with a FIA 05 flow injection analyser. The trophic (oligotrophic) and humic (oligo- to periodically mesohumic) status of Lake Gjerstadvann was determined based on the total phosphorous and $\mathrm{KMnO}_{4}$-demand/water colour, respectively (Tab. 1B). 
a)

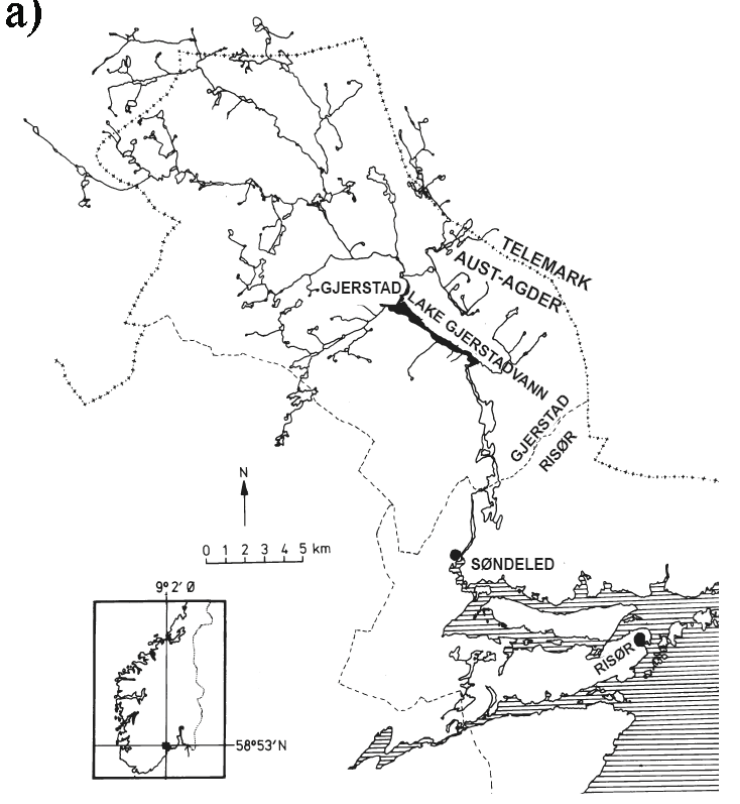

b)

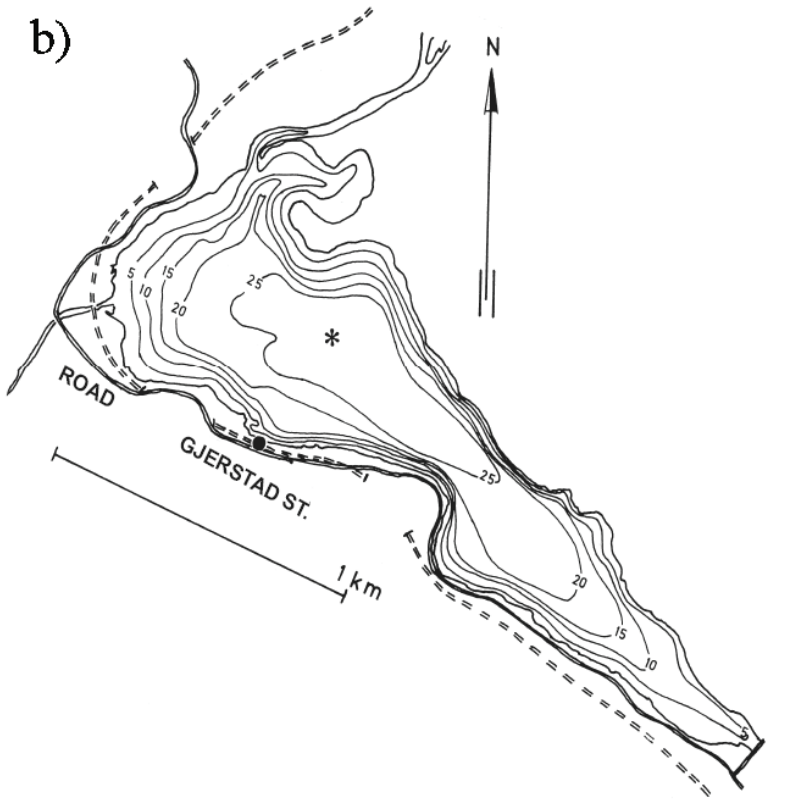

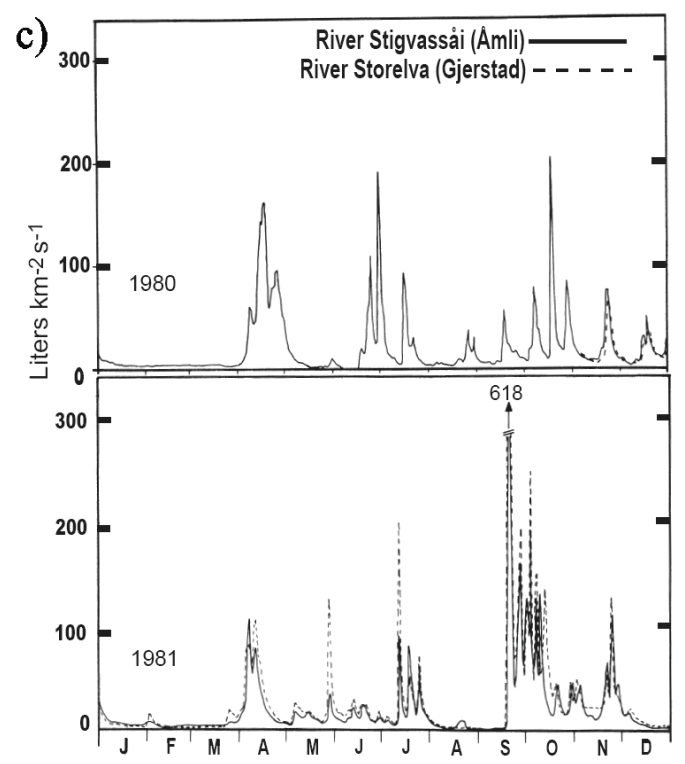

Fig. 1. Geographical position of Lake Gjerstadvann (upper and lower basin) in southern Norway (a), (b) depth map of Lake Gjerstadvann upper basin with sampling station $\left(^{*}\right)$ and (c) waterflow of the major incoming River Storelva (---- ; no available data before November 1980) and a neighbouring River Stigvassåi ( — ; used as a proxy).

Biological samples were collected at the fixed station at depths and frequences as reported for the chemical samples described above. Phytoplankton samples were taken using a Ruttner sampler, and integrated from 1-10 m before they were counted quantitatively. Duplicate quantitative zooplankton samples were collected using a 15 liter Patalas/Schindler device (Schindler 1969), with an attached net $(45 \mu \mathrm{m})$. Zooplankton densities were calculated according to representative depth volumes (Tab. 1A), determined by the hypsographic curve. In addition, qualitative zooplankton samples were collected with vertical tows from the bottom to the surface with plankton nets (diameter $25 \mathrm{~cm}$, mesh size 90 and $224 \mu \mathrm{m}$ ). Sampling of diapausing stages in the sediment at all lake depths was performed with a quantitative core sampler with inner diameter $6.1 \mathrm{~cm}$ (Skogheim 1979), and sediment samples were treated according to Elgmork (1959) and Nilssen \& Elgmork (1977). Diapause intensity (torpidity) was based on animals reviving after 2, in contrast to the usual 3, mechanical disturbances (Elgmork 1959; Nilssen \& Elgmork 1977), because of the low degree of torpidity of M. leuckarti and T. oithonoides in Lake Gjerstadvann.

Most metazoan zooplankton (Tab. 2) were identified to species (Rylov 1963; Flössner 1972; Ruttner-Kolisko 1972; Einsle 1975; Kiefer 1978). Ontogenetic stages of copepods were separated and counted, except for the cyclopoid nauplii which were calculated based on their 
Tab. 2. List of all metazoan species collected in the pelagial of Lake Gjerstadvann in 1980/81. Relative abundance within each group of animals is indicated as: $\mathrm{XXX}=$ dominating, $\mathrm{XX}=$ frequent, $\mathrm{X}=$ few specimens and $\mathrm{R}=$ rare.

\begin{tabular}{|c|c|c|c|}
\hline \multicolumn{2}{|l|}{ Rotifera: } & \multicolumn{2}{|l|}{ Cladocera: } \\
\hline Kellicottia longispina (Kellicott, 1879) & $\mathrm{XXX}$ & Bosmina longispina Leydig, 1860 & XXX \\
\hline Conochilus unicornis/hippocrepis & & Holopedium gibberum Zaddach, 1855 & $\mathrm{XX}$ \\
\hline Rousselet, 1892/(Schrank, 1803) & $x \times x$ & Diaphanosoma brachyurum (Liéven, 1848) & $\mathrm{XX}$ \\
\hline Polyarthra spp. Ehrb., 1834 & $\mathrm{XXX}$ & Polyphemus pediculus (Linnaeus, 1761) & $\mathrm{X}$ \\
\hline Keratella hiemalis Carlin, 1943 & $\mathrm{XX}$ & Bythotrephes longimanus Leydig, 1860 & $\mathrm{X}$ \\
\hline Keratella cochlearis (Gosse, 1851) & $\mathrm{XX}$ & Ceriodaphnia quadrangula (O.F. Müller, 1776) & $\mathrm{X}$ \\
\hline Keratella serrulata (Ehrb., 1838) & $\mathrm{X}$ & Leptodora kindti (Focke, 1844) & $\mathrm{X}$ \\
\hline Keratella ticinensis (Callerrio, 1921) & $\mathrm{X}$ & Chydoridae spp. Stebbing, 1902 & $\mathrm{X}$ \\
\hline Keratella testudo (Ehrb., 1832) & $\mathrm{R}$ & Scapholeberis mucronata (O.F. Müller, 1776) & $\mathrm{R}$ \\
\hline Collotheca cf. libera (Zacharias, 1894) & $\mathrm{X}$ & Sida crystallina (O.F. Müller, 1776) & $\mathrm{R}$ \\
\hline Collotheca lie-petterseni Bērziņš, 1951 & $\mathrm{X}$ & Daphnia lacustris G.O. Sars, 1862 & $\mathrm{R}$ \\
\hline Ascomorpha ecaudis Perty, 1850 & $\mathrm{X}$ & & \\
\hline Lecane sp. Nitzsch, 1827 & $\mathrm{X}$ & Insecta: & \\
\hline Synchaeta sp. Ehrb., 1832 & $\mathrm{X}$ & Chaoborus flavicans (Meigen, 1830) & $\mathrm{X}$ \\
\hline Euchlanis dilatata Ehrb., 1832 & $\mathrm{R}$ & & \\
\hline Trichocerca sp. Lamarck, 1801 & $\mathrm{R}$ & Copepoda: & \\
\hline Asplanchna priodonta Gosse, 1850 & $\mathrm{R}$ & Eudiaptomus gracilis (G.O. Sars, 1863) & XXX \\
\hline Gastropus stylifer Imhof, 1891 & $\mathrm{R}$ & Heterocope saliens (Lilljeborg, 1863) & $\mathrm{R}$ \\
\hline \multirow[t]{3}{*}{ Gastropus minor (Rousselet, 1892) } & $\mathrm{R}$ & & \\
\hline & & Cyclops scutifer G.O. Sars, 1863 & $\mathrm{XXX}$ \\
\hline & & Mesocyclops leuckarti (Claus, 1857) & $\mathrm{XX}$ \\
\hline Fish: & & Thermocyclops oithonoides (G.O. Sars, 1863) & $\mathrm{X}$ \\
\hline Perca fluviatilis Linnaeus, 1758 & $\mathrm{XXX}$ & Cyclops abyssorum G.O. Sars, 1863 & $\mathrm{R}$ \\
\hline Salmo trutta Linnaeus, 1758 & $\mathrm{XX}$ & Diacyclops nanus (G.O. Sars, 1863) & $\mathrm{R}$ \\
\hline Coregonus lavaretus (Linnaeus, 1758) & $\mathrm{X}$ & Diacyclops bicuspidatus (Claus, 1857) & $\mathrm{R}$ \\
\hline Salvelinus alpinus (Linnaeus, 1758) & $\mathrm{R}$ & Megacyclops gigas (Claus, 1857) & $\mathrm{R}$ \\
\hline
\end{tabular}

different body-sizes and the different life cycles of the species. The few typical littoral and benthic species (mainly Megacyclops gigas, Diacyclops nanus, and D. bicuspidatus) recorded in the lake pelagial, were identified to species, but not included in the quantitative or qualitative analyses.

The generations of E. gracilis in Lake Gjerstadvann were identified and developmental times (from females with eggs to the next generation of females with eggs) were calculated. Eckstein (1964) calculated the developmental time for individuals in a laboratory population of E. gracilis. His data were compared with development rates of E. gracilis in Lake Gjerstadvann. Since the first spring generation (1.S.G.) of copepods often develops at temporary food saturation (Allan 1976; Nilssen 1978), we compared this 1.S.G. of E. gracilis in Lake Gjerstadvann with several neighbouring lakes. Similarily, the rate of development of M. leuckarti in Lake Gjerstadvann was compared with laboratory animals offered optimal food (Vijverberg 1980).

The share of males was calculated as percentage males of total adults, the share of females with eggs as percentage of total females, and clutch size as mean number of eggs per egg-carrying females (both egg-sacs were included for cyclopoids). Eggs per total females and eggs per litre were calculated from total egg numbers in the sample divided with total females and sample volume (in litres), respectively. Total body lengths, including caudal rami (furca), were measured on at least 20 adult females (if present) each sampling date.
The fish species present in Lake Gjerstadvann are listed in table 2. Fish sampling and analysis of fish food items were performed as described by Linløkken (1985) and Vethe (1988), respectively. Eurasian perch was the dominant fish species, and brown trout was frequently captured (Linløkken 1985; Linløkken 1988; Vethe 1988). A few specimens of charr were collected, and whitefish was found in small numbers. Few specimens of the phantom midge Chaoborus flavicans were collected in the pelagial (Tab. 2), also during night time (Wærvågen, unpubl. data). The species was an important fish food item throughout most of the year in Lake Gjerstadvann (Vethe 1988).

\subsection{Study area}

This region of southern Norway (Fig. 1a) has a continental climate with a substantial oceanic influence with considerable seasonal changes in water chemistry; during spring due to snow melting and during autumn due to seasonal rainfalls (Fig. 1c). Lake Gjerstadvann is dimictic, with bottom temperatures slightly above $4{ }^{\circ} \mathrm{C}$ in the ice-free period (Fig. 2). It had a deep circulating layer because of its considerable flow-through (Figs 1 and 2). The lake is situated $31 \mathrm{~m}$ a.s.l., below the previous post-glacial marine limit, about $100 \mathrm{~m}$ a.s.l. in this region. The annual mean $\mathrm{pH}$ in Lake Gjerstadvann was 5.2 (Tab. 1B), but slightly below this value during icebreak up, autumn and summer rain periods (Figs 1c and 2). Usually lakes below the marine limit have a much higher $\mathrm{pH}$ and fewer factors associated with acidifica- 

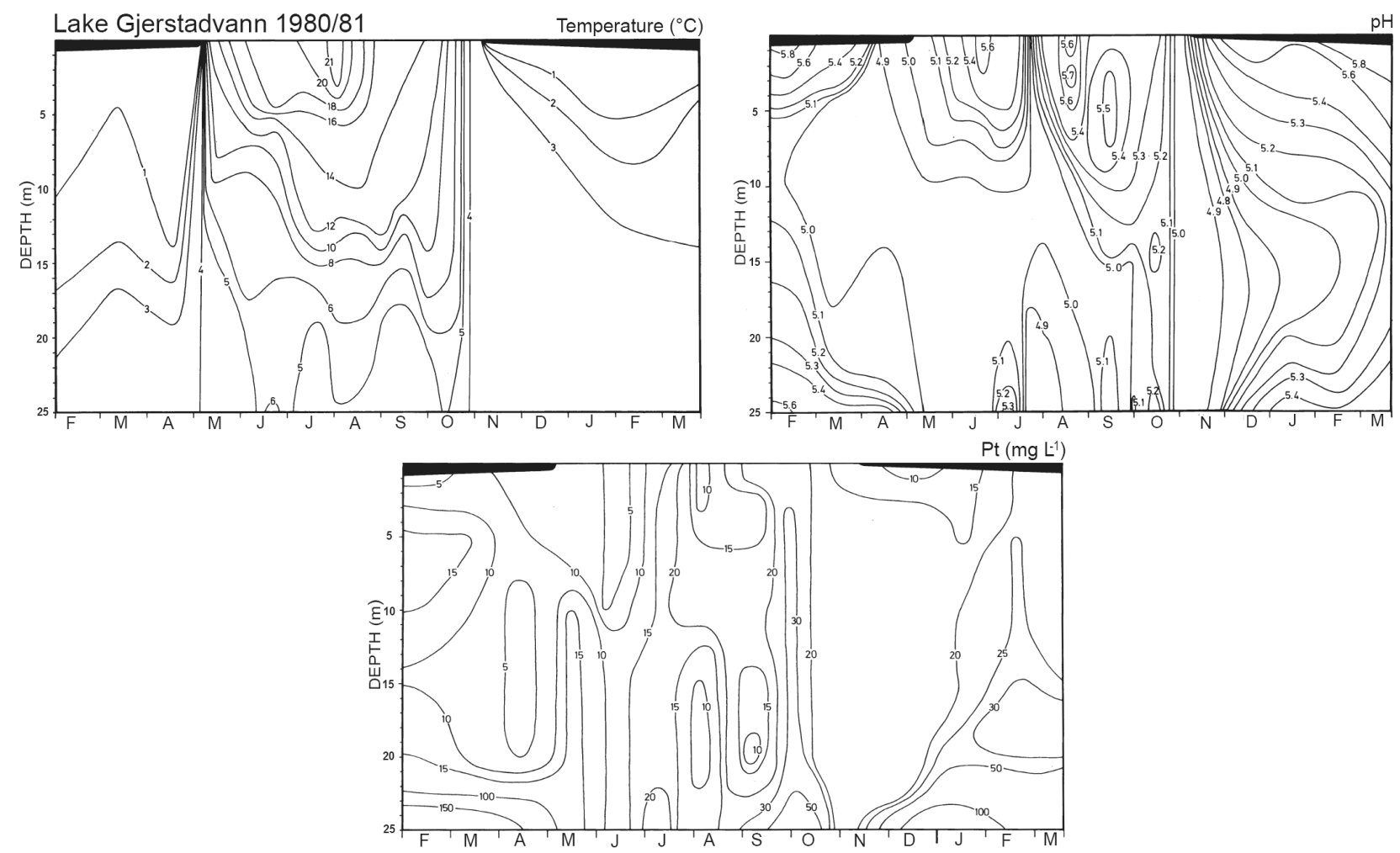

Fig. 2. Isoplots for temperature, $\mathrm{pH}$ and water colour $\left(\mathrm{mg} \mathrm{Pt} \mathrm{L}^{-1}\right)$ in Lake Gjerstadvann 1980-1981. Ice cover is shown in real dimensions as black bars here and in similar figures.

tion (e.g., lower aluminium, higher calcium concentrations, less pronounced seasonal $\mathrm{pH}$ oscillations) than Lake Gjerstadvann (Nilssen 1980b; Fjerdingstad \& Nilssen 1982). However, most of the catchment area of Lake Gjerstadvann is situated above the postglacial marine limit, thus draining chronically acidified regions (Nilssen 1980b; Fjerdingstad \& Nilssen 1982) with mean pH 4.7 in 1980 (Hindar et al. 1984).

Lake Gjerstadvann was oligotrophic and oligomesohumic at the time of this investigation (Tab. 1B). The colour of the epilimnetic lake water was $10-30 \mathrm{mg}$ $\mathrm{Pt} \mathrm{L}^{-1}$, which increased considerably above the profundal sediments (Fig. 2). The oxygen content was slightly below 100 percent during most of the year, with an oxygen deficit close to the bottom during periods of stagnation (Wærvågen 1985), most probably due to the inlets' transport of organic material (Fig. 2). Higher annual mean temperatures have probably resulted in larger amounts of organic materials being transported into the lake water in recent decades, with an associated increase in water colour (Nilssen \& Wærvågen 2001).

Concentrations of RAl were $200-250 \mu \mathrm{g} \mathrm{L}^{-1}$ (Tab. 1B), increasing during the spring spate and autumn rain periods and decreasing in the upper water masses during summer (Wærvågen 1985). Part of this RAl is attached to humic material (Lydersen 1998), and the labile fraction (lAl) at these ambient $\mathrm{pH}$ values are about 40-70 percent of the RAl values (Lydersen 1998). The 1Al exceeded probably more than $100 \mu \mathrm{g} \mathrm{L}^{-1}$ in Lake Gjer- stadvann in 1980-81, which suggested a negative ambient water influence on all fish species present in the lake (Hesthagen et al. 2001). The concentration of reactive aluminium (RAl) has decreased considerably during the most recent decades with increasing $\mathrm{pH}$ (Nilssen \& Wærvågen 2001), and this is probably also the case for the poisonous labile aluminium (1Al) fraction.

Specific conductivity increased the last two decades before this study in 1980-81, due to an increase in soil weathering and atmospherically transported substances (Nilssen 1982). In 1980-81 the $\mathrm{Ca}^{2+}$ content was close to $2.0 \mathrm{mg} \mathrm{L}^{-1}, \mathrm{Na}^{+}$around $1.2 \mathrm{mg} \mathrm{L}^{-1}, \mathrm{~K}^{+} 0.5 \mathrm{mg} \mathrm{L}^{-1}$, sulphate $6 \mathrm{mg} \mathrm{L}^{-1}$, and other chemical parameters shown

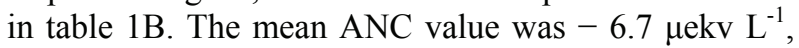
which probably also negatively influenced the fish biota of the lake (Hesthagen et al. 2001).

\section{RESULTS}

\subsection{Seasonal population dynamics and spatial distribution}

In the ice-free months (May-November), Eudiaptomus gracilis was most abundant during three distinct time periods (Fig. 3). Nauplii of E. gracilis originating from the winter population were first registered during late May. Nauplii were distributed in the whole water column, but were most numerous above the thermocline (Fig. 3). Copepodids I-IV were predominantly restricted to the summer period, with a main distribution in the 

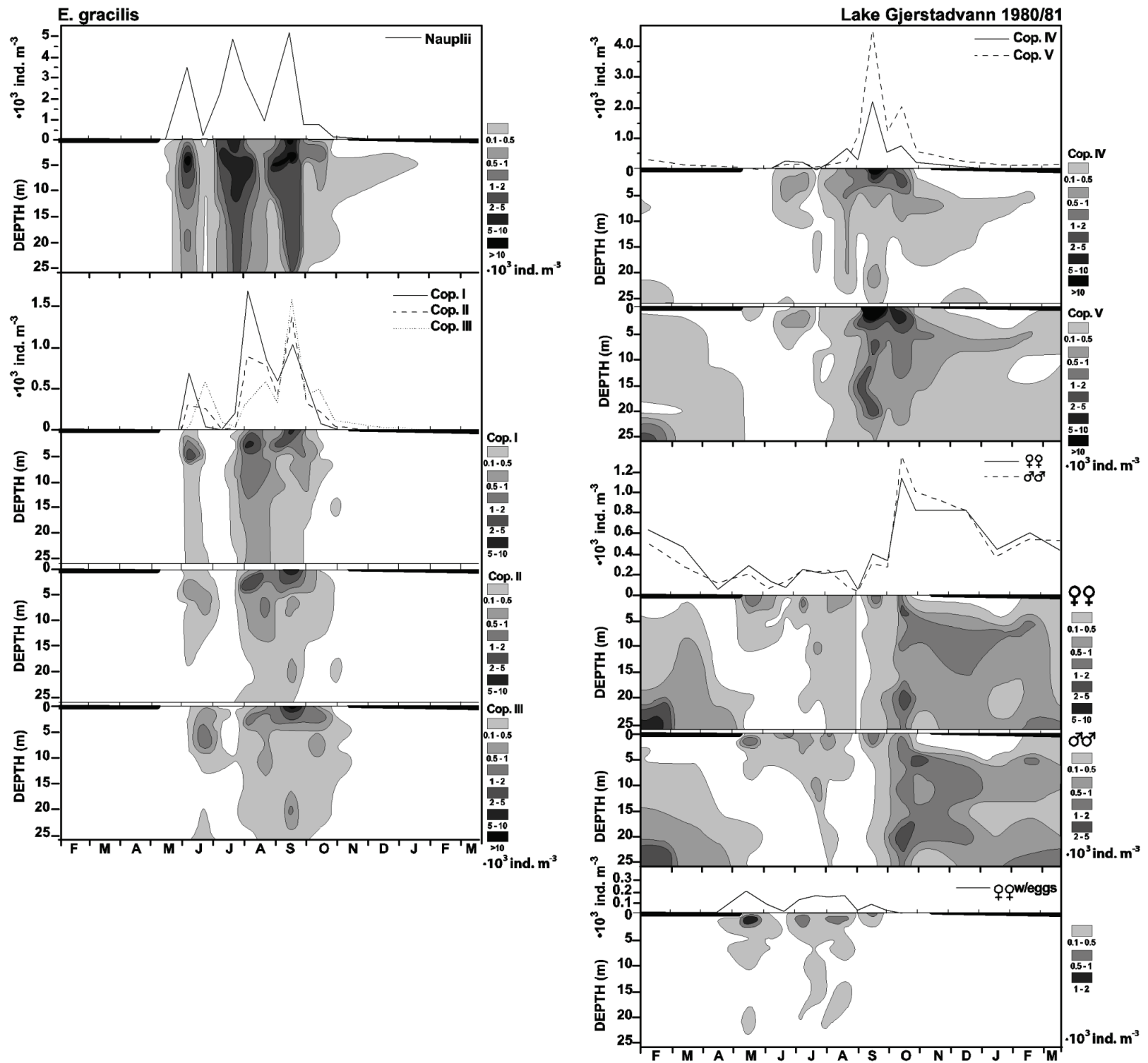

Fig. 3. Mean population density (upper panels) and vertical distribution (lower panels) of all ontogenetic stages and females with eggs of Eudiaptomus gracilis during 1980/1981.

upper water masses. Adults and cop V were collected in all seasons, whereas egg-carrying females were recorded only in the ice-free period. Adults without eggsacs and cop V were distributed in the whole water column. Egg-carrying females displayed three population peaks, similar to those of their naupliar offspring (Fig. 3). Mean population densities (Fig. 4) ranged from 2 to 5 individuals $\mathrm{L}^{-1}$, with a maximum in September at 16 ind $\mathrm{L}^{-1}$

Based on the detailed analysis of size relationship of adult females (Fig. 5) and by studying the life cycle of E. gracilis (Fig. 6), the different generations were identified. The generations included the first summer (1.S.G.), second summer in epilimnion (2.S.G.-Epi), second summer in hypolimnion (2.S.G.-Hypo), and third summer generations (3.S.G.) (Figs 5 and 6; Tab. 3). The percentage deviation of the developmental time of each generation, when compared with laboratory data (Eckstein 1964), was rather small. We consistently found a slightly longer developmental time for individuals in the lake compared with laboratory animals (Tab. 3). These percentage deviations increased for the 2.S.G.-Epi and 3.S.G. by 16 and 19 percent, respectively. Food was scarce at these occasions (Fig. 7), and the small clutch size also supports the existence of suboptimal nutritional conditions (Figs 4 and 7). In addition, higher water temperatures imply that more energy is being used for maintainance in the epilimnion during summer. Animals developing at lower water temperatures have decreased metabolic rates, such as 2.S.G.Hypo which showed less deviation from the Eckstein's data (7 percent). In addition, increased allochthonous food seemed to positively influence the 2.S.G.-Hypo cohort (Figs 2 and 7). 

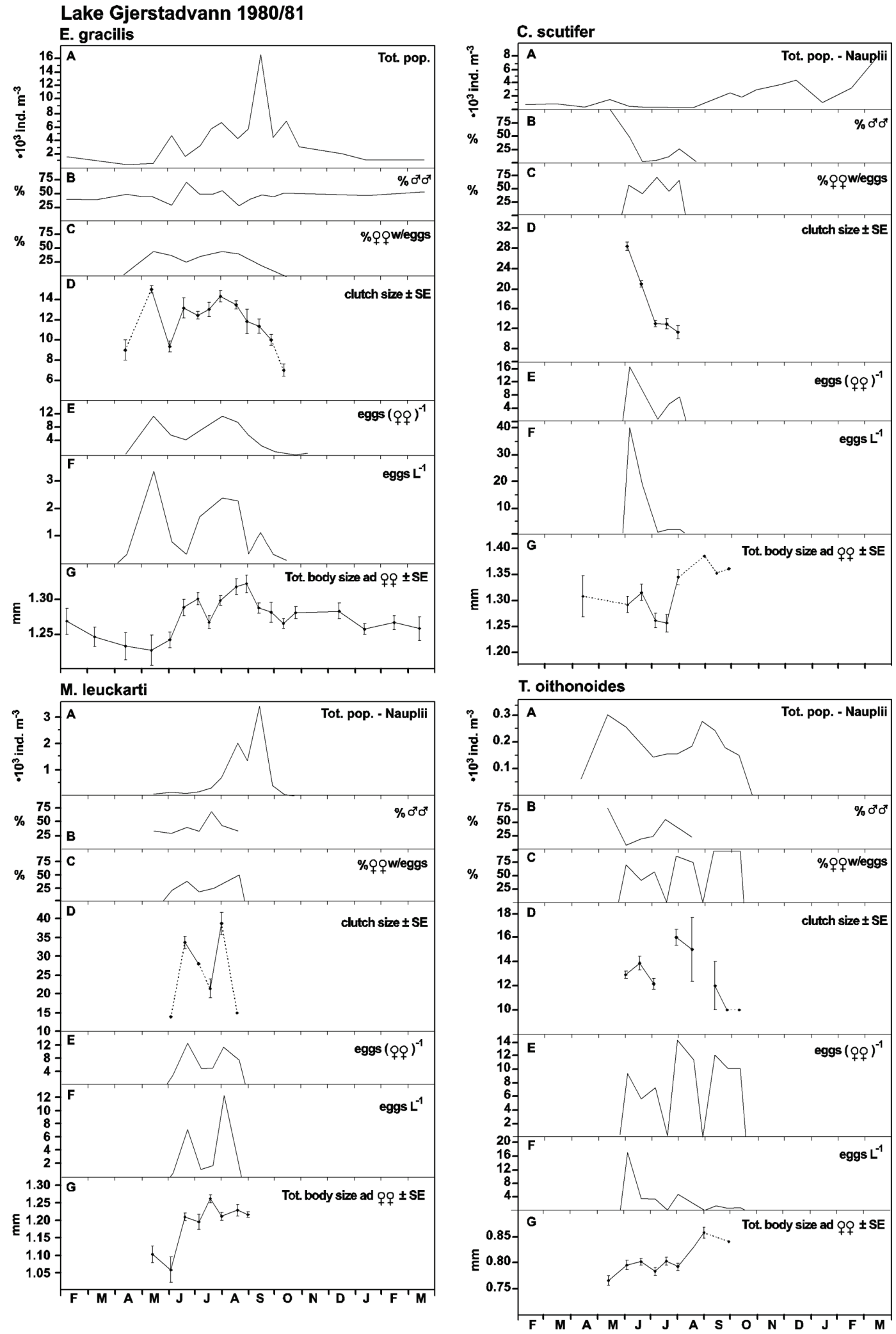

Fig. 4. Selected parameters of life histories of each species: total mean densities (for cyclopoid copepods calculated without the naplii); \% males; \% females with eggs; clutch size (eggs per egg-carrying female); eggs per total females; eggs per litre; and total body size of adult females of Eudiaptomus gracilis, Cyclops scutifer, Mesocyclops leuckarti, and Thermocyclops oithonoides during 1980/1981. Dotted lines indicate few specimens. 


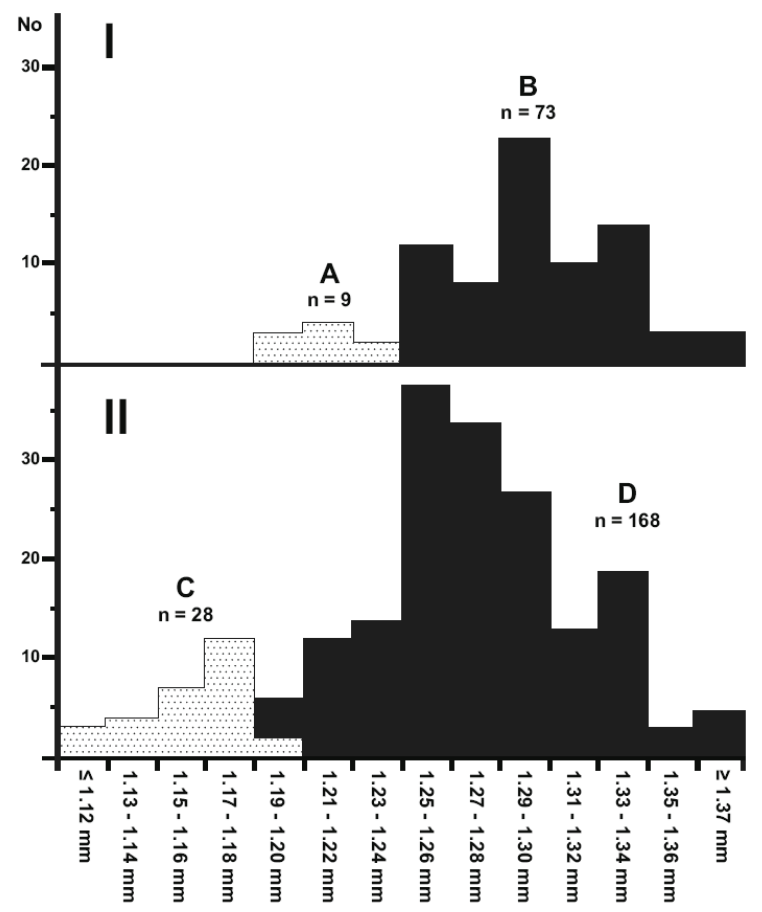

Fig. 5. Size relationship (total body length) of the different cohorts of Eudiaptomus gracilis in Lake Gjerstadvann. A: 2.S.G.-Epi (second summer generation - epilimnetic fraction), B: 1.S.G. (first summer generation), C: 3.S.G. (third summer generation), and D: 2.S.G.-Hypo (second summer generation - hypolimnetic fraction). I: animals from 21 June until 20 August 1980; II: animals from 8 February until 15 May 1980 plus from 15 September 1980 until 13 March 1981.
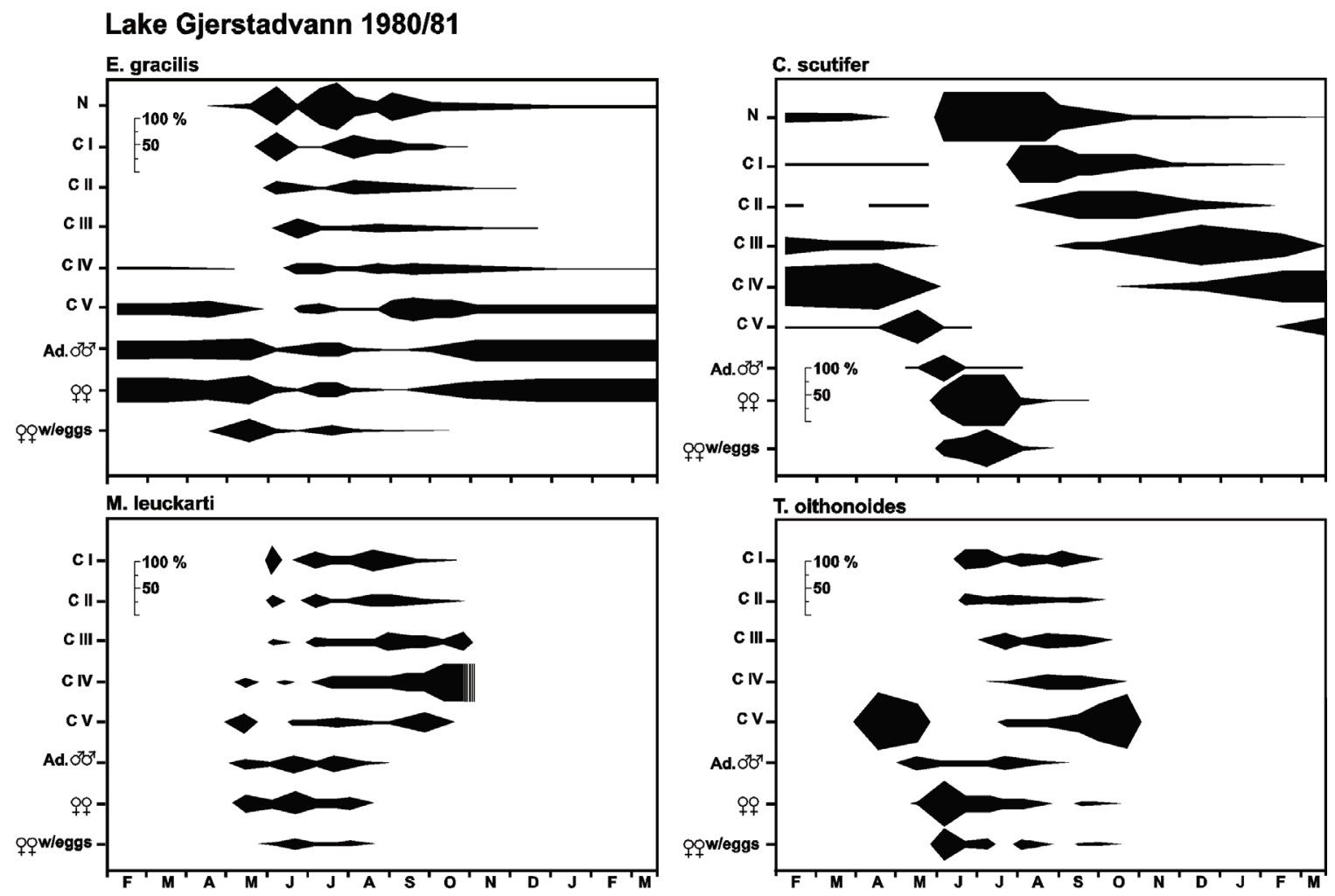

Fig. 6. Life cycles of Eudiaptomus gracilis, Cyclops scutifer, Mesocyclops leuckarti, and Thermocyclops oithonoides during 1980/1981. For E. gracilis and C. scutifer nauplii are included, for M. leuckarti and T. oithonoides nauplii are excluded. 
Tab. 3. Developmental time of different generations and cohorts of Eudiaptomus gracilis in 1980/1981, and developmental time recorded for a laboratory population by Eckstein (1964). 1.S.G. (first summer generation), 2.S.G.-Epi (second summer generation epilimnetic fraction), 2.S.G.-Hypo (second summer generation - hypolimnetic fraction), 3.S.G. (third summer generation). $\dagger=$ fourth generation. $\mathrm{E}=$ eggs (on ovigerous females), $\mathrm{N}=$ nauplii, and $\mathrm{C}=$ copepodids.

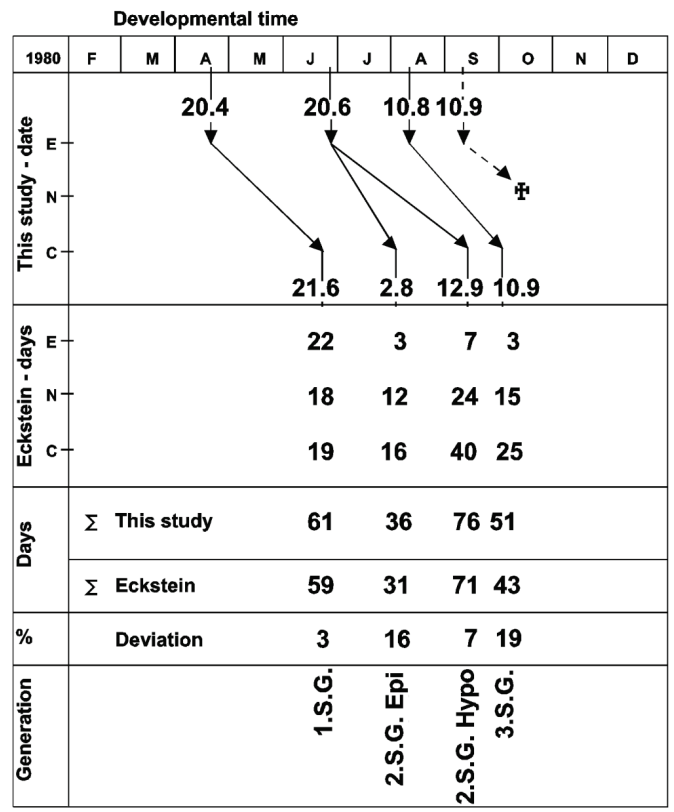

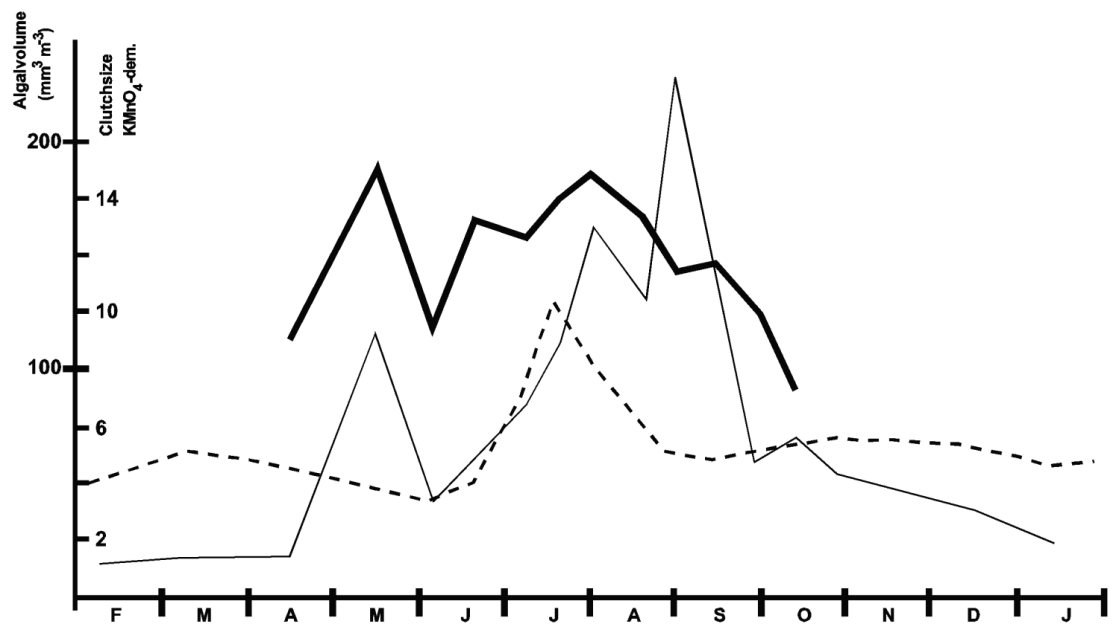

Fig. 7. Clutch size (thick line) of Eudiaptomus gracilis in Lake Gjerstadvann during 1980/1981 related to food availability: mean phytoplankton biomass (algal volume - thin line) and detritus $\left(\mathrm{KMnO}_{4}\right.$-demand as $\mathrm{mg} \mathrm{O}_{2} \mathrm{~L}^{-1}$ - dashed line).

The winter population was composed of a combination of 2.S.G.-Hypo and 3.S.G., because no reproduction took place after these individuals developed into adults in September/October (Figs 4 and 6). Probably both these cohorts reproduced the following year after ice-break (Figs 3 and 6). Many conditions must be fulfilled for production of a successful late summer generation (3.S.G.), and these requirements did not appear to be met in Lake Gjerstadvann, the 3.S.G. constituted only about 14 percent of the total winter population (Fig. 5). Attempts to produce a fourth generation of $E$. gracilis failed after mid-October probably due to low food availability and a high flushing rate (Fig. 7; Tab. 3).
The developmental times of different 1.S.G. of $E$. gracilis related to ambient development temperatures in several neighbouring lakes is shown in figure 8. A significant positive relationship was observed between temperature and developmental time during spring and early summer (Fig. 8), suggesting that food conditions were less important for developmental times during this period of temporary food saturation.

Nauplii of Cyclops scutifer displayed a peak in abundance during summer, mainly in the meta- and hypolimnion, but were collected most of the year (Fig. 9). 


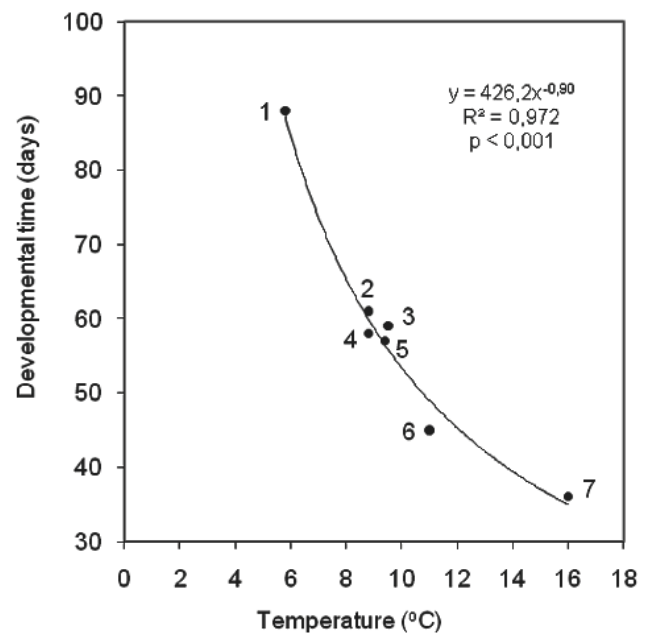

Fig. 8. Correlation between developmental time of Eudiaptomus gracilis first summer generations and water temperatures, recorded from females with eggs through the entire life cycle in Lake Gjerstadvann during 1980/1981 and adjacent (see table 5) populations (1: Lake Skuggetjenn-1981, 2: Lake Gjerstadvann-1.S.G.-1980, 3: Lake Vormelitjenn-1981, 4: Lake Skuggetjenn-1980, 5: Lake Bosviktjenn-1981, 6: Lake Fievann-1978, 7: Lake Gjerstadvann-2.S.G.-Epi-1980).
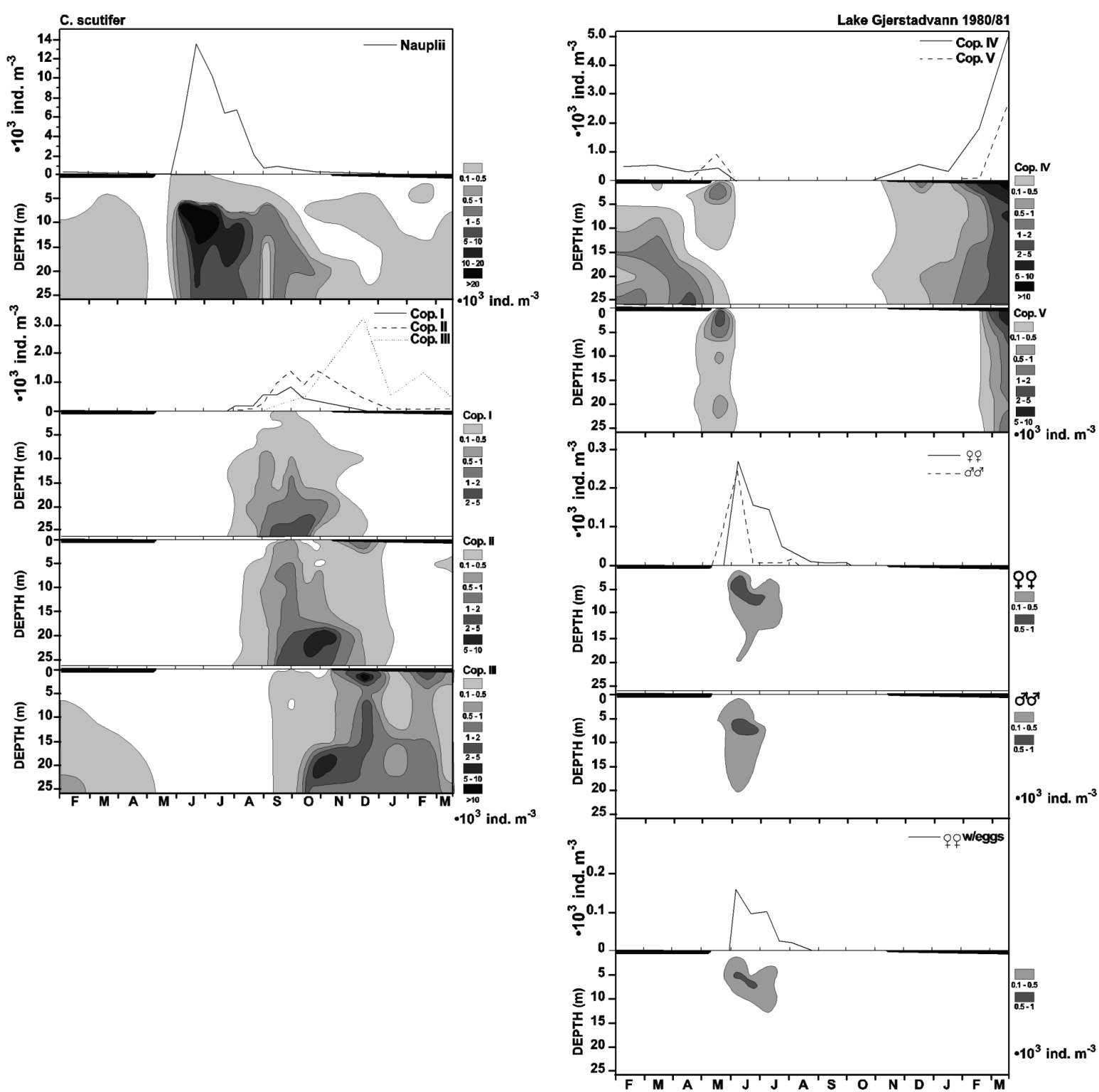

Fig. 9. Mean population density (upper panels) and vertical distribution (lower panels) of all ontogenetic stages and females with eggs of Cyclops scutifer during 1980/1981. 

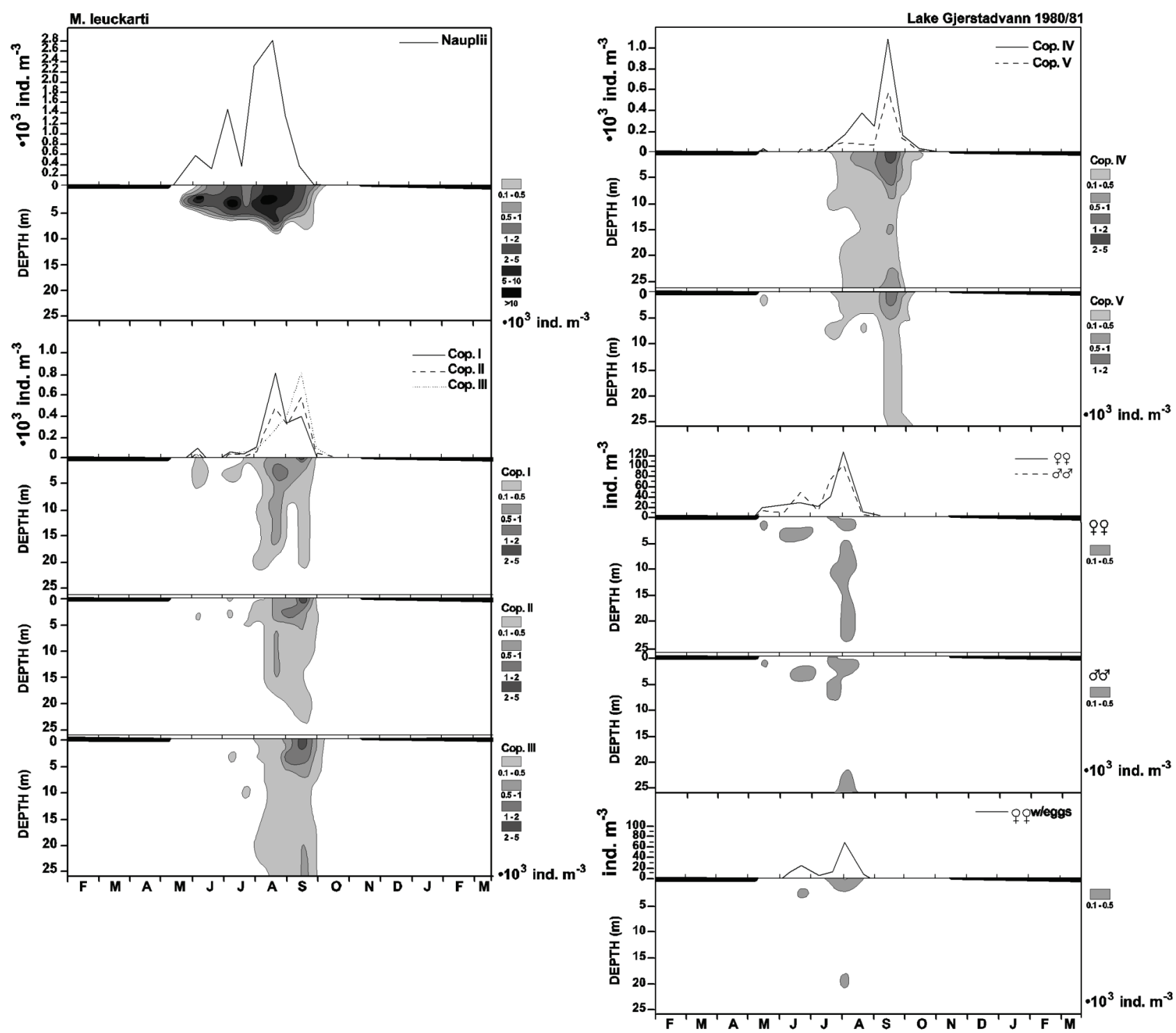

Fig. 10. Mean population density (upper panels) and vertical distribution (lower panels) of all ontogenetic stages and females with eggs of Mesocyclops leuckarti during 1980/1981.

The early copepodids (cop I-III) of C. scutifer were mainly observed in deeper layers during autumn and winter, and advanced copepodids (cop IV-V) were distributed under the ice and could also be collected immediately after ice break-up. The rapid migration of the main cop IV population towards the warmer surface water after ice breakage was a conspicuous trait (Fig. 9). Most cop IV developed into cop V in the upper water masses, and were thereafter distributed through the whole water column. By contrast, the adults and females with eggs were found in the epilimnion in a restricted summer period in Lake Gjerstadvann (Fig. 9). The males disappeared during July, whereas the longer-living females were collected throughout August. Both cop IV and V showed considerable interannual variations, with about five and three times higher population densities in 1981 compared with 1980.

All instars of Mesocyclops leuckarti were mainly recorded in the upper water masses, but some animals were observed towards the bottom (Fig. 10). The main peak of M. leuckarti was detected in August-September, when the population accumulated in the diapausing stage. Diapause, initiated from early October, was represented mainly by individuals in cop V and a small cop IV fraction, predominantly in the littoral sediments of the lake (Fig. 11A). In the winter 1980/81 they were collected from the uppermost part (exceeding $25 \times 10^{3}$ ind $\mathrm{m}^{-2}$ ), and in 1983/84 and 1984/85 in lower part (below $10 \times 10^{3}$ ind $\mathrm{m}^{-2}$ ) of the littoral zone. The first emergence from diapause and development into adults 


\section{Lake Gjerstadvann 1980/85}
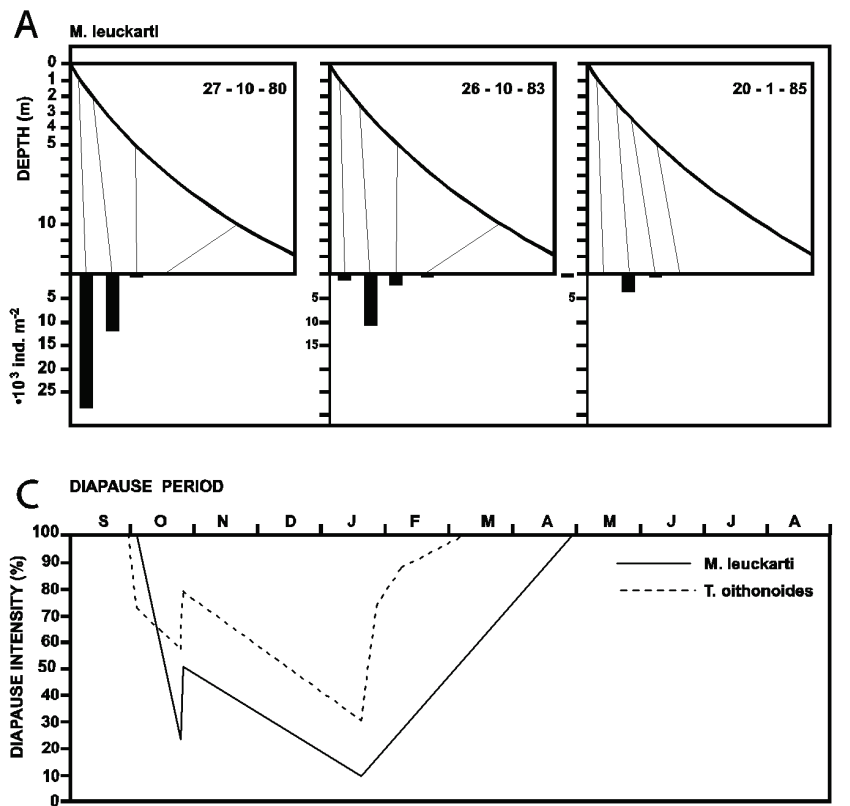

B T. olthonoldes

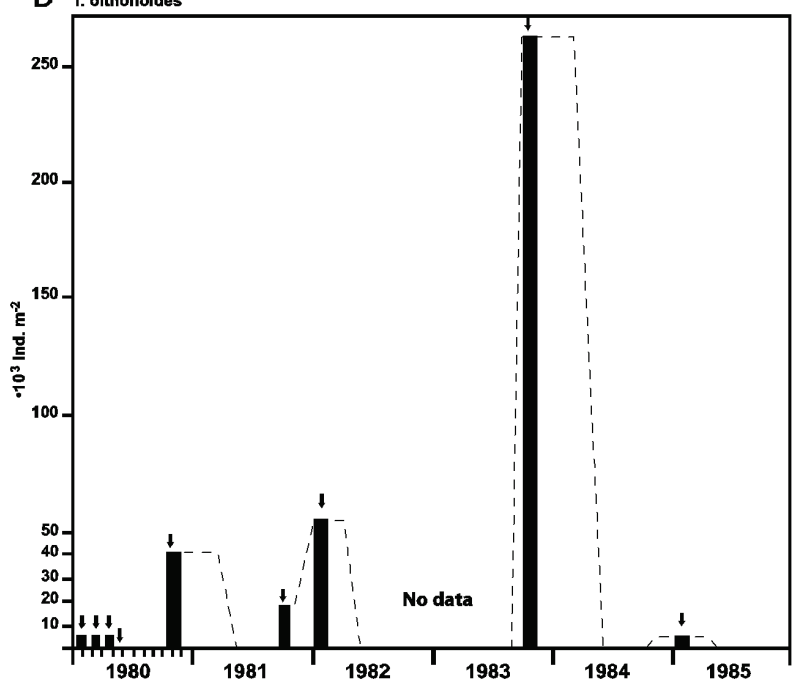

Fig. 11. Distribution and abundance of resting late copepodid instars of Mesocyclops leuckarti (A; littoral) and (B; profundal) Thermocyclops oithonoides for indicated years, and (C) seasonal diapause intensity (torpidity) of resting copepodids of M. leuckarti and T. oithonoides in Lake Gjerstadvann.

probably took place in this zone of the lake as well (Fig. $10)$.

The main population of Thermocyclops oithonoides was observed in the upper water masses (Fig. 12). This species is a more typical pelagic component than $M$. leuckarti, and therefore most of its ontogenetic stages were collected close to the surface. Males were collected throughout August, and females until mid-October, when the adult population vanished. The habitat for diapausing $T$. oithonoides was exclusively the deepest part of the lake (Fig. 11B). The diapausing stage cop V migrated vertically from the sediment into the upper water masses during spring, and towards the bottom into the sediment to diapause during autumn (Fig. 12). The interannual variations in resting animal densities were noticeable, with variations from below $5 \times 10^{3}$ ind $\mathrm{m}^{-2}$ in the winter $1979 / 80$ and $1984 / 85$ to large densities exceeding $250 \times 10^{3}$ ind $\mathrm{m}^{-2}$ in 1983/84 (Fig. 11B).

M. leuckarti characteristically selected the shallow littoral areas to diapause in sediment, whereas $T$. oithonoides was distributed at deeper strata (Fig. 11). Diapause in $T$. oithonoides and M. leuckarti lasted for about 5 and 7 months, respectively, in Lake Gjerstadvann (Fig. 11C). Variations in intensity of diapause (torpidity) with time and site is a general feature of copepod dormancy. Both during the early phase and termination of the diapause period torpidity decreased (Fig. 11C). Diapause was noticeably less intense in $T$. oithonoides than in M. leuckarti, but both species demonstrated low degree of torpidity (see Methods) in Lake Gjerstadvann (Fig. 11C).

\subsection{Reproductive and life history parameters}

The life cycle of E. gracilis, based upon the percentage distribution of the different ontogenetic stages, is shown in figure 6. The quantitative results (Fig. 3) indicated three different generations of E. gracilis in Lake Gjerstadvann, but the second and third generation showed temporal overlap (Fig. 6). Portion of males was close to 50 percent, especially during the winter period (Fig. 4). In the later part of the first and second reproductive periods, males decreased to about 30 percent (Fig. 4), probably due to their shorter life span. Egg-carrying females were abundant during the whole ice-free period, representing up to 40 percent of all females during May and first part of August.

Clutch size of $E$. gracilis varied between 1-26 eggs per female (annual mean $=13.0, \mathrm{~N}=306$ ), and for each observation date the mean ranged from 7.0-15.0 eggs per female (Fig. 4). Eggs per female showed two identifiable peaks, whereas the prolonged second peak most likely contained both the second and third generation. Egg density showed three peaks comparable to the three annual generations (Figs 4 and 6). Total body length of the adult females (Fig. 4) reached a minimum (1.15 $\mathrm{mm}$ ) during late winter/early spring, extending to a short summer maximum and a prolonged autumn maximum $(1.35 \mathrm{~mm})$, and the annual mean was $1.27 \mathrm{~mm}(\mathrm{~N}=311)$.

C. scutifer produced one yearly generation in Lake Gjerstadvann (Fig. 6). The population of C. scutifer was much larger during 1980/81 than in 1979/80, mainly with late copepodids and a minor naupliar fraction in 


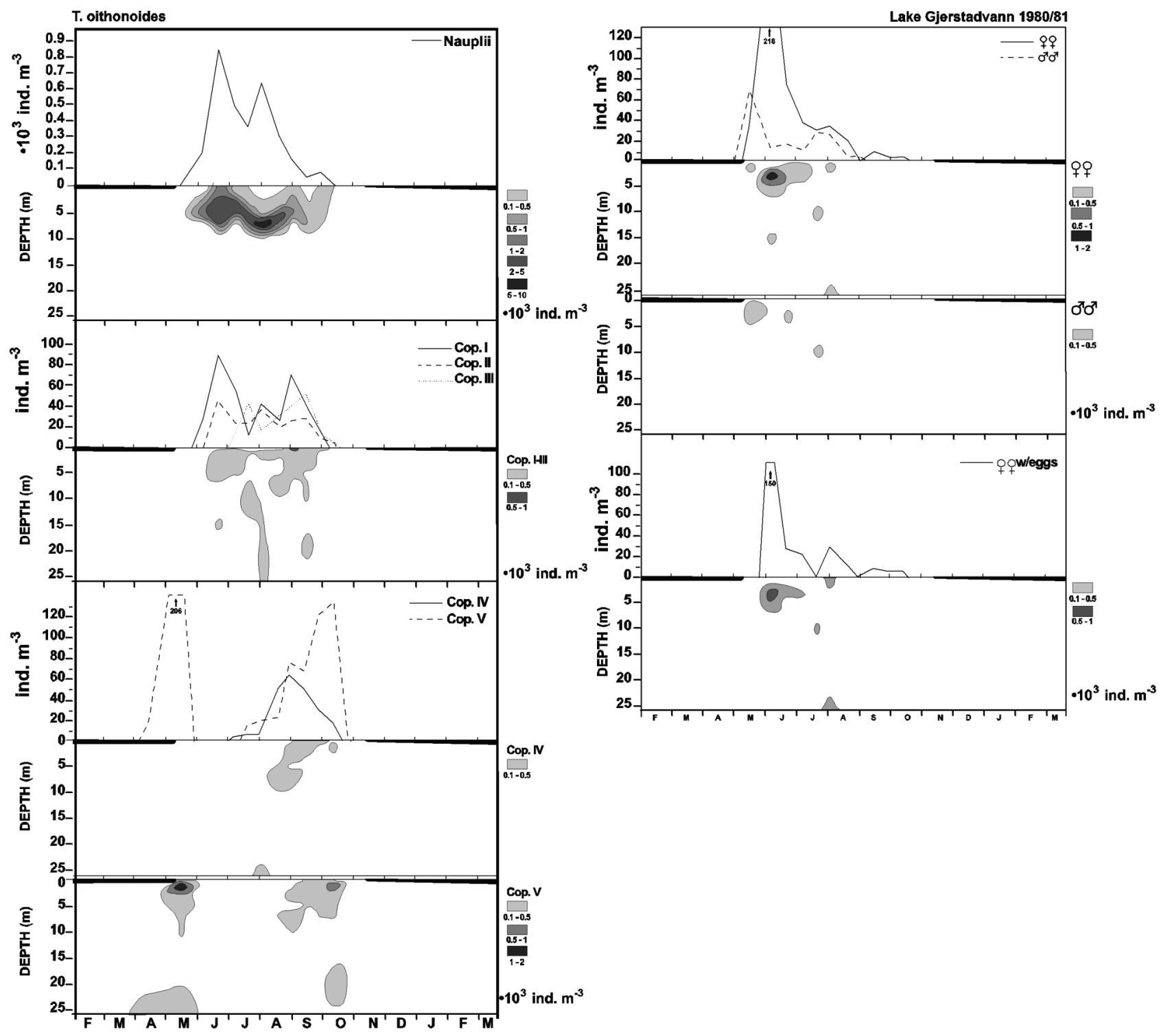

Fig. 12. Mean population density (upper panels) and vertical distribution (lower panels) of all ontogenetic stages and females with eggs of Thermocyclops oithonoides during 1980/1981.

the plankton during the ice period (Fig. 9). Males were abundant during the early reproductive period and decreased sharply towards the end of this period (Figs 4 and 9). The percentage of egg-carrying females was high from June to August, but the major reproductive period with largest clutch sizes was in early June (Fig. 4). Clutch size of $C$. scutifer varied between 10-38 eggs per female (annual mean $=21.2, \mathrm{~N}=83$ ), and for each observation date the mean ranged from 11.3-28.5 eggs per female (Fig. 4), decreasing during the entire reproductive period. The mean body size of adult females of C. scutifer was about $1.3 \mathrm{~mm}$ in the early reproductive period, close to the annual mean $1.29 \mathrm{~mm}(\mathrm{~N}=93)$, and decreasing to $1.25 \mathrm{~mm}$ during August; a few specimens of about $1.4 \mathrm{~mm}$ was found in September (Fig. 4).

M. leuckarti displayed three annual generations, a prolonged stay in late copepodid stages IV and V in autumn until diapause was initiated during October/November (Figs 6 and 11). M. leuckarti showed a main summer population density in the pelagic (Fig. 10 ), with a larger part of the spring and autumn population distributed in the littoral sub-system. The rate of development for this species in Lake Gjerstadvann was compared to laboratory animals offered optimal food (Tab. 4). The rate of development was noticeably slower in $M$. leuckarti in Lake Gjerstadvann compared with laboratory animals (Tab. 4), in contrast to E. gracilis where the difference was negligible (Tab. 3). This indicates that sub-optimal food conditions exsist for $M$. leuckarti in Lake Gjerstadvann.

The percentage of males for M. leuckarti was close to 50 percent most of the period (Fig. 4). Both the percentage of females with eggs, eggs per females, and density of eggs displayed two peaks (Fig. 4). Clutch size 
Tab. 4. Developmental time of three different summer generations (1.-3.S.G.) of Mesocyclops leuckarti in Lake Gjerstadvann during 1980/1981, and in laboratory specimens (Vijverberg 1980). *due to diapause in cop V, development time (days) from copV-ad. are estimated.

\begin{tabular}{|c|c|c|c|c|}
\hline $\begin{array}{l}\text { Generation } \\
\text { ontogeny }\end{array}$ & $\begin{array}{c}\text { Temperature } \\
\left({ }^{\circ} \mathrm{C}\right)\end{array}$ & $\begin{array}{l}\text { Laboratory study } \\
\text { Developmental time } \\
\text { (days) }\end{array}$ & $\begin{array}{c}\text { This study Growing season } \\
\text { Developmental time } \\
\text { (days) }\end{array}$ & $\begin{array}{l}\text { Percentage } \\
\text { deviation } \\
(\%)\end{array}$ \\
\hline \multicolumn{5}{|l|}{ 1.S.G. } \\
\hline Eggs & 14 & 4 & From 20.05 & \\
\hline N I-VI & 18 & 7 & & \\
\hline C I-V & 18 & 10 & Until 20.06 & \\
\hline Eggs-adults & & 21 & 30 & 43 \\
\hline \multicolumn{5}{|l|}{ 2.S.G. } \\
\hline Eggs & 19 & 2 & From 20.06 & \\
\hline N I-VI & 19 & 6 & & \\
\hline C I-V & 17 & 11 & Until 20.07 & \\
\hline Eggs-adults & & 19 & 30 & 58 \\
\hline \multicolumn{5}{|l|}{ 3.S.G. } \\
\hline Eggs & 21 & 2 & From 05.08 & \\
\hline N I-VI & 19 & 6 & & \\
\hline C I-V & 13 & 15 & Until 20.09* & \\
\hline Eggs-adults & & 23 & 45 & 96 \\
\hline
\end{tabular}

of $M$. leuckarti varied between 12-54 eggs per female (annual mean $=34.6, \mathrm{~N}=30$ ), and for each observation date the mean ranged from 21.5-38.7 eggs per female $( \pm 15.0$ early and late in the reproductive period with small $\mathrm{N} \pm 2$, see dotted line in figure 4). The intermediate summer minimum in clutch size coincided in time with a temporary $\mathrm{pH}$-suppression due to heavy seasonal rainfall (Figs 1c and 2). The first generation of $M$. leuckarti females in spring were relatively small-sized (1.1 $\mathrm{mm})$, the annual mean was $1.21 \mathrm{~mm}(\mathrm{~N}=77)$, whereas in later generations body size exceeded $1.2 \mathrm{~mm}$ (Fig. 4).

$T$. oithonoides showed a combination of two and three generations per year (Fig. 6), because the second generation could either develop into adults (the rapid developmental line) or delay its development in cop V until entering sediment diapause. Males were dominant early in the reproductive period, but decreased towards the end (Fig. 4). Both the percentage females with eggs, eggs per female, and density of eggs supported the existence of three possible annual generations. Since developmental time of $T$. oithonoides was slower than M. leuckarti, the temporal separation of its reproductive traits was more distinct (Fig. 4). Clutch size of $T$. oithonoides varied between 10-20 eggs per female (annual mean $=13.3, \mathrm{~N}=61$ ), and for each observation date the mean ranged from 10.0-16.0 eggs per female (Fig. 4). Annual mean body size of T. oithonoides was small, $0.80 \mathrm{~mm}(\mathrm{~N}=85)$ (Fig. 4).

The total mean population density of $C$. scutifer was slightly lower than E. gracilis, and both M. leuckarti and $T$. oithonoides was below that of these two species, where the latter displayed the lowest population density of these four copepods in Lake Gjerstadvann (Fig. 4). The rare species Cyclops abyssorum was exclusively registered in hypolimnion of Lake Gjerstadvann at irregular periods of the year (Wærvågen \& Nilssen unpubl. data). Its appearance during winter in the plankton, and the fact that it has never been recorded in the sediments here and in neighbouring lakes, probably indicates that the species is planktonic throughout the year without resting stages in Lake Gjerstadvann. A few specimens of the other rare species, the large-sized calanoid Heterocope saliens, were found in the upper water masses, mainly during early summer (Wærvågen $\&$ Nilssen unpubl. data).

\section{DISCUSSION}

\subsection{Calanoid copepods - reproductive and life history parameters}

The most common freshwater calanoid copepod in low altitude areas of Europe is Eudiaptomus gracilis (Kiefer 1978; Bohonak et al. 2006). The species is euryoeceous and adapted to a whole array of environmental conditions e.g. from the most acidic to alkaline, and from oligotrophic to eutrophic (Kiefer 1978). E. gracilis is extremely tolerant towards ecosystem stress such as acidification (Nilssen \& Wærvågen 2003). Together with the cladoceran Bosmina longispina and the copepod H. saliens, E. gracilis is the only crustacean to tolerate chronic and long-term acidic conditions (Nilssen 1980b; Hobæk \& Raddum 1980; Morling \& Pejler 1990). During periods when the environment is less acidic and under eutrophic conditions, E. gracilis may decrease in abundance (Maier \& Buchholz 1996), probably because of increasing fish predation on females with eggs (Ponyi \& Zánkai 1982; Brabrand et al. 1987; Svensson 1996). In Lake Gjerstadvann, fish predation on zooplankton was mainly restricted to largesized cladocerans, such as Bythotrephes longimanus, and to a lesser extent $B$. longispina and Leptodora kindti (Vethe 1988). Fish also consumed some few late instars of pelagic copepod species, such as E. gracilis and $C$. scutifer mainly during early spring (Vethe 1988). These 
consumption, small and restricted in time, probably did not influence population numbers of these two most abundant copepods in Lake Gjerstadvann.

The potential food availability of $E$. gracilis in Lake Gjerstadvann included autochthonous (phytoplankton) and allochthonous (detritus) food. Clutch size is an indicator of the nutritional status of the species in a given locality (e.g., Elgmork 2006), and ranged from 7.0-15.0 $($ mean $=13.0)$ eggs per female, which were quite high values when compared to other field studies (Czeczuga 1959; Chapman 1969; Ponyi et al. 1975; Ponyi \& Zankai 1982), and in laboratory populations (Berger \& Maier 2001). Clutch size displayed a spring peak coinciding with the seasonal phytoplankton outburst, a summer peak coinciding with a maximum in detritus and phytoplankton, and a third peak coinciding with the autumnal algal maximum.

Food availability is an important parameter also affecting the outcome of different generations of $E$. gracilis in Lake Gjerstadvann. A major obstacle in identifying different generations and cohorts of $E$. gracilis in nature, is their frequent overlap due to different development rates in different parts of the species' sub-habitats (Elster 1954; Eckstein 1964; Einsle 1964). For instance, in Lake Gjerstadvann, we observed epilimnetic and hypolimnetic summer generations or cohorts. We consistently found slightly longer developmental times for individuals in the lake compared with laboratory animals (Eckstein 1964). The smallest discrepancy was observed for the first summer generation (1.S.G.), which coincided with the seasonal outburst of algae. This first summer generation was established before the cladoceran competitors achieved large population sizes (Wærvågen 1985), as generally observed (Allan 1976; Nilssen 1980a). Such short development times of E. gracilis comparable to laboratory conditions suggested that food conditions were less important for developmental times during this period of temporary food saturation. These developmental rates were in accordance with published data (Munro 1974). Clutch sizes was high during this period, supporting the hypothesis of reliance on optimal food conditions (e.g., Czeczuga 1959; Chapman 1969).

E. gracilis in Lake Gjerstadvann produced three successful generations, including one generation with two different cohorts. Life histories in field populations of $E$. gracilis in Palaearctic can vary considerably from 1 to 11 generations (for references see table 5). Generally the number of generations increases with increasing ambient food quality and temperature, or nutritional status of the site (Ref. in table 5). In this study, we recorded reproduction and highest density of $E$. gracilis in Lake Gjerstadvann in epilimnion. In most other lakes, E. gracilis was distributed in the epilimnion as well, but advanced instars and adults were often observed deeper in the water column (Elster 1954; Larsen 1982; Sandøy 1984), as also recorded in Lake Gjerstadvann.
The dominance of adults in the winter population of E. gracilis has been reported for the majority of populations studied (Elster 1954; Chapman 1969; Sandøy 1984; Demmo 1985; Næss 1985). Males constituted close to 50 percent during the reproductive period indicating the requirement for repeated insemination (Kantona 1975; Berger \& Maier 2001). A positive relationship has been found between clutch size and food availability (Elster 1954; Czeczuga 1960; Smyly 1968; Ponyi et al. 1975), but Hofman (1979) reported that increasing lake production did not seem to augment clutch size. However, an interrelation between fish predation and clutch size may be present in several populations (Svensson 1996). In Lake Gjerstadvann, the total body length of adult females ranged from $1.15 \mathrm{~mm}$ during late winter/early spring to a autumn maximum of 1.35 $\mathrm{mm}$, which indicates low fish predation on this species.

Tab. 5. Number of generations of Eudiaptomus gracilis in different lakes in its biogeographical region compared to this study; adjacent lakes $(*)$ and other European sites (see references).

\begin{tabular}{cll}
\hline No. of generations Site & Reference \\
\hline 1 & Loch Lomond & Chapman (1969) \\
1 & Lake Østre Kalvvann* & Nilssen (unpubl. data) \\
2 & Lake Krasavitsa & Ivanova (1961) \\
2 & Lake Heilandsvann* & Nilssen (unpubl. data) \\
3 & Lake Schleinsee & Kutzne (1938) \\
3 & Lake Skuggetjenn* & Sandøy (1984) \\
3 & Lake Gjerstadvann & This study \\
4 & Lake Fievann* & Larsen (1982) \\
4 & Lake Bosviktjenn* & Demmo (1985) \\
4 & Lake Vormelitjenn* & Næss (1985) \\
$5-6$ & Lake Bodensee-Obersee & Elster (1954) \\
7 & Lake Schluchsees & Eckstein (1964) \\
$9-11$ & Lake Balaton & Zankai (1978) \\
\hline
\end{tabular}

In Lake Gjerstadvann, Heterocope saliens was found only in the upper water masses, mainly during early summer. This large-sized calanoid (total body size 2.5$3.2 \mathrm{~mm}$ ) is common in the acidified lakes with relaxed fish predation of this region (Nilssen 1980b). Due to the historical and current predation from fish (e.g., Nilssen \& Wærvågen 2003), the size of its egg bank has probably never reached the high densities observed in the fishless lakes adjacent to Lake Gjerstadvann (Sandøy \& Nilssen 1987a). H. saliens was scarce in Lake Gjerstadvann, as in other perch lakes (Nilssen \& Wærvågen 2003).

\subsection{Cyclopoid copepods - reproductive and life history parameters}

Cyclops scutifer is among the most typical boreal copepod, distributed over a large part of the northern hemisphere (Rylov 1963; Elgmork \& Halvorsen 1998; Elgmork 2004, 2006). Outside the taiga, C. scutifer is found on the European continent only in the lowlands to the north (Poland) and in the Baltic region (Illies 1978; Kiefer 1978). In the Nearctic, C. scutifer is distributed 
from arctic Alaska and arctic Canada to Maine and Connecticut in northeastern USA (Elgmork 2004). In agreement with its boreal distribution, C. scutifer is considered a moderately cold stenothermic species (Bertilsson et al. 1995; Elgmork 2006), even if it can endure relatively high temperatures. Accordingly, the main population of $C$. scutifer in Lake Gjerstadvann was observed in water colder than $14{ }^{\circ} \mathrm{C}$. Adults are more frequently collected at higher temperatures than younger ontogenetic instars. In Lake Gjerstadvann, adults were observed at $18{ }^{\circ} \mathrm{C}$. This is in accordance with earlier observations where this species was recorded at similar temperatures (Halvorsen \& Elgmork 1976; Elgmork \& Langeland 1980; Demmo 1985). Cop V appeared about one month earlier in 1981, compared with 1980. This could be due to higher water temperatures during autumn 1980 and the following winter.

C. scutifer shows a relatively wide tolerance towards chemical factors (Nilssen \& Wærvågen 2003). It is usually recorded in oligotrophic lakes, but can also be found in more eutrophic and alkaline environments (Elgmork 2006). The hypolimnetic C. scutifer is, however, sensitive to strong and permanent acidification, and specifically disappears following acidification below $\mathrm{pH} 4.5$ from shallower localities (Nilssen \& Wærvågen 2003). Further, this species seems able to sustain viable populations in deeper acidic lakes, probably due to the more stable and slightly higher $\mathrm{pH}$ in hypolimnion compared with the upper water masses (Nilssen \& Wærvågen 2003). Consequently, the C. scutifer population density in Lake Gjerstadvann was probably slightly suppressed due to the low $\mathrm{pH}$-level and elevated RAl, and population densities were likely fluctuating following seasonal changes in acidity during the period of egg and naupliar production. Both cop IV and $\mathrm{V}$ showed considerable variations in the two years of sampling, with more than five and three times higher population densities in 1981, respectively, compared to 1980. This could be due to the different ambient $\mathrm{pH}$ those two years (e.g., Sandøy \& Nilssen 1987b). During 1980, most of the egg-carrying period of C. scutifer took place before the acidic summer rain, and the vulnerable egg-stage consequently avoided the detrimental acidic conditions.

Life cycles of $C$. scutifer display extreme variations, ranging from 1-year cycles, combined 1- and 2-year cycles, and even 3-year cycles both with and without diapause (Elgmork 1965, 1967, 1985). The great variation in life cycles may partly be due to genetic differences (Twombly 1995), but water temperatures (Elgmork 2004, 2006) and food conditions (Smyly 1970) probably play a major role.

In $C$. scutifer, two co-existing cohorts have frequently been recorded during winter consisting of late copepodids and nauplii (Lindström 1952, 1958; Axelson 1961; Nilssen 1977; Elgmork et al. 1978), which in many cases was due to different co-occurring year classes (Elgmork 2006). In Lake Gjerstadvann, however, it was due to the existence of two cohorts with 1year life cycle, one with late copepodids (the dominant line) and another with nauplii, during winter. Females originating from the overwintering nauplii probably reproduced during the latest part of the reproductive period, but a certain amount of overlap probably occurred between these two cohorts. A 1-year life cycle is common in C. scutifer (Elgmork 2006). Splitting of the population with differing development rates for the various cohorts of $C$. scutifer has been frequently recorded (Halvorsen \& Elgmork 1976; Elgmork et al. 1978), and this prolongation can involve both diapause arrest in the sediment or so-called "active diapause" in the plankton (Halvorsen \& Elgmork 1976; Krylov et al. 1996). This physiological state includes arrested development, lack of significant gut contents, and the presence of large, orange lipid droplets in the body cavity (Elgmork 1962). No sediment diapause was registered for C. scutifer in Lake Gjerstadvann. The winter plankton phase for the late copepodids could also in this lake be characterised as "active diapause", since the specimens had empty stomachs and were filled with coloured oil droplets, similar to animals in sediment diapause (Elgmork 1959; Nilssen \& Elgmork 1977).

C. scutifer showed 1-year and 2-year life cycles in lakes neighbouring the site of this study. In lakes with low fish predation, the winter populations were dominated by advanced copepodids (Sandøy 1984). Nilssen (1977, 1980a) hypothesised that splitting into cohorts during wintering was caused by fish predation combined with synchronising life cycles for utilising early summer food. This period can frequently be considered as a "cladoceran vacuum" in lake ecosystems (e.g., Allan 1976), where slow-developing copepods have a selective advantage by being present before cladocerans awake from their resting eggs and build up large populations (Nilssen 1980a).

The main reproductive period for the omnivorous $C$. scutifer started after a production peak of phytoplankton, as also registered by other authors (e.g., Alimov et al. 1972; Monakov 1972; Larsson 1978). Females with egg sacs were observed for a prolonged period until August, after the majority of males had disappeared from the plankton. Females of cyclopoid copepods are able to store sperm for a considerable period of time without remating (Næss \& Nilssen 1991). Reproduction of $C$. scutifer coincided with large densities of rotifers (Wærvågen 1985), which are possible food items (Monakov 1972; Larsson 1978). Clutch size varied from about 30 eggs during spring and decreased to about 10 eggs in the last part of the reproductive period, probably related to food availability. Further, clutch size decreased with increasing age of the females, decreasing abundance of rotifers and increased algal abundance.

The feeding activity of fish in Lake Gjerstadvann was low during winter, when mainly benthic copepods 
were consumed (Vethe 1988). Reduced fish predation seems to favour life cycles with advanced copepodids in the winter population (Nilssen 1977, 1980a), in accordance to this study. In lakes with intensive perch predation, life cycles during most of the year were dominated by the nauplii fraction (Demmo 1985; Skov 1985), which has a body size refuge from fish predation (Nilssen 1977, 1980a; Elgmork et al. 1978). During icebreak in Lake Gjerstadvann, C. scutifer was recorded in the stomachs of Eurasian perch, but to a negligible extent (Vethe 1988). In the present study, the body size of adult females of C. scutifer was about $1.3 \mathrm{~mm}$ in the early reproductive period, decreasing slightly during August, whereas a small female population with body size about $1.4 \mathrm{~mm}$ was found in late autumn, which is relatively normal for an oligotrophic lake (Rylov 1963). The impact of fish predation on C. scutifer is probably negligible in Lake Gjerstadvann.

Mesocyclops leuckarti and Thermocyclops oithonoides are two characteristic boreal species, distributed over a large part of the Palaearctic, especially in the central and southern parts (Elgmork 1958, 1964; Rylov 1963; Kiefer 1978; Nilssen \& Wærvågen 2000). They probably migrated there from the Ponto-Caspian region after the last Ice Age (Nilssen \& Wærvågen 2000). The distribution range of $T$. oithonoides is considerably smaller than that of M. leuckarti. The zoogeographical area of overlap of the two species is delimited by the low altitudinal parts of Fennoscandia, the eastern part of Europe and north of the Alps up to Denmark. In agreement with their more southern boreal distribution than C. scutifer, these two species are considered warm-water species (Bertilsson et al. 1995; Nilssen \& Wærvågen 2000). Vijverberg (1980) and Herzig (1983) showed that both $M$. leuckarti and $T$. oithonoides develop comparably slower at low temperatures. Smyly (1974) found that $M$. leuckarti developed very slowly at $4{ }^{\circ} \mathrm{C}$, showing high egg mortality. Kiefer (1978) reported that $M$. leuckarti eggs did not develop below $6{ }^{\circ} \mathrm{C}$ and that nauplii had a stagnation in growth at a temperature below 8 ${ }^{\circ} \mathrm{C}$. Herzig (1983) indicated a genetic component in the embryonic development of M. leuckarti, as also registered for C. scutifer (Twombly 1995), but all populations of $M$. leuckarti developed rapidly at temperatures above $18{ }^{\circ} \mathrm{C}$.

M. leuckarti and T. oithonoides display a wide tolerance towards chemical environments (Kiefer 1978; Nilssen \& Wærvågen 2000). They are recorded in lakes of all types of trophy, somewhere between oligotrophy and marked eutrophy, with $M$. leuckarti being the most tolerant towards extremely productive systems (Nilssen \& Wærvågen 2000). T. oithonoides is seldom recorded above the postglacial marine limit in the surveyed region (Fig. 1a). It is never recorded in strongly acidic sites, but it shows increasing abundance as a consequence of decreased acidity associated with natural recovery and liming (Nilssen \& Wærvågen 2003). The least sensitive of all the pelagic cyclopoid copepods in Lake Gjerstadvann towards acidification is M. leuckarti.

M. leuckarti in Lake Gjerstadvann produced three yearly generations during the ice free period. However, the rate of development was slow compared with laboratory animals offered optimal food (Vijverberg 1980). This underscores the existence of sub-optimal food conditions for cyclopoid copepods such as M. leuckarti in Lake Gjerstadvann, whereas the omnivorous E. gracilis showed development rates comparable to laboratory animals (Eckstein 1964). In neighbouring lakes $M$. leuckarti produced both diannual and triannual life cycles, depending upon interannual variations in habitat temperatures (Sandøy 1984). In addition, ambient physiological stress, such as low $\mathrm{pH}$, could add to slower developmental rate. Many M. leuckarti populations are described to produce two generations each year (Smyly 1961; Elgmork 1964; Mittelholzer 1970; Stebler 1979; Nyberg 1981). The common distribution of this species in the plankton is from March to October, and in sediment diapause as cop IV-V during winter (Nilssen \& Wærvågen 2000). Some populations in the southern part of the geographical distribution area inhabit the plankton during the whole year (Nilssen \& Wærvågen 2000).

The common life cycle of $T$. oithonoides is a combination of two or three generations a year (Nilssen \& Wærvågen 2000), as it occured in Lake Gjerstadvann. In sites where the species entered diapause earlier in the season, it produced only two generations per year (Næss et al. 1993), whereas in the localities where it entered diapause later in the season, it was more likely to produce three annual generations (Næss et al. 1993).

In our study, both $M$. leuckarti and $T$. oithonoides inhabited the epilimnion, whereas $T$. oithonoides seemed to be distributed slightly deeper in the water column than M. leuckarti. In lakes without M. leuckarti, $T$. oithonoides was found closer to the surface (Næss 1985; Demmo 1985). The plankton distribution in Lake Gjerstadvann was also reflected in the bathymetric depth distribution of the resting stages in the sediment. M. leuckarti characteristically selected the shallow littoral areas to diapause in sediment, whereas $T$. oithonoides was distributed at deeper strata. The interannual differences between the diapausing populations were a conspicuous trait both in M. leuckarti and T. oithonoides, and could be due to the fluctuating acidification of the epilimnion of the lake, as already reported by Sandøy \& Nilssen (1987b).

In Norwegian lakes, T. oithonoides is more susceptible to low $\mathrm{pH}$ than M. leuckarti (Nilssen \& Wærvågen 2000). T. oithonoides is probably the most acid-vulnerable of all recorded species in Lake Gjerstadvann (Nilssen \& Wærvågen 2003), and may, in this lake be close to its physiological pH-tolerance. Therefore, annual variations in population numbers of this species in acid-stressed lakes may be the rule rather than the 
exception, which is also supported by the interannual diapause alterations. In the late autumn of 1983 water probably had a higher $\mathrm{pH}$ than in 1984, due to large differences in autumn rainfall (e.g., Kleiven et al. 1990).

In the present study, the first emergence of $M$. leuckarti from diapause and development into adults probably took place in the littoral zone. Water temperatures in littoral sites, such as shallow ponds and lakes, follow more closely the air temperatures throughout the year. Gieysztor (1960) studied this phenomenon in detail, also involving diurnal measurements during different times of the year. Littoral areas, especially strata where M. leuckarti frequently diapauses, are subjected to much higher temperatures during spring, up to $10{ }^{\circ} \mathrm{C}$ higher than in the pelagic epilimnion (Gieysztor 1960). High temperatures may lead to earlier revival from diapause (Maier 1989, 1990). M. leuckarti is known for its tendency to utilise the littoral sub-system during periods of low fish predation in this zone (Nilssen \& Wærvågen 2000). In 1980, Lake Gjerstadvann still harboured a considerable population of Eurasian perch, which reproduced during June (Linløkken 1988). Accordingly, the following population peak of adult $M$. leuckarti in Lake Gjerstadvann was observed in the pelagial, coinciding in time with the accumulation of YOY-perch in the littoral region (Wærvågen \& Nilssen, unpubl. data).

This conspicuous habitat shift of the adult females of $M$. leuckarti seems to be a common phenomenon, with several plausible explanations. Adult females of $M$. leuckarti with egg-sacs are more vulnerable to predation than copepodid stages, and males (e.g., Winfield \& Townsend 1983). To avoid or decrease this predation, adult females select the littoral area or regions close to the bottom as their preferred habitat at specific times of the year, such as spring and the early summer period (Nilssen \& Wærvågen 2000). Additionally, the littoral and profundal areas offer a variety of prey species for invertebrate predators, like the predaceous adult females of $M$. leuckarti (body length 1.1-1.3 mm). M. leuckarti seems to be more carnivorous than expected solely based on body size (Hansen \& Santer 1995; Hopp et al. 1997), and even its smaller copepodids seem more carnivorous than similar-sized or even larger cyclopoids (Hansen \& Santer 1995). M. leuckarti needed animal food to produce a high number of viable offspring (Hansen \& Santer 1995; Hopp et al. 1997). Monakov \& Sorokin (1959) and Brandl \& Fernando (1979) reported that juveniles of the plankton-littoral species D. brachyurum comprised important food for advanced stages of Mesocyclops. Moreover, M. leuckarti has been found to utilize detritus as food (Papinska 1985), and the littoral zone is characterised by such food items.

Also habitat selection of diapause of $M$. leuckarti may also be influenced by potential prey availability in that specific site. Several species of cladocerans, such as D. brachyurum (see Herzig 1984) and B. longispina, distribute their resting stages in the littoral as well. Both cladocerans terminate egg diapause at times comparable to the carnivorous late copepodids and adults of $M$. leuckarti (Wærvågen \& Nilssen, unpubl. data). The latter thus have attractive prey with small body sizes available at a critical time during its ontogenetical development. Finally, the much higher littoral temperatures offer more rapid development of the eggs and a possibility to produce more eggs at shorter time intervals of $M$. leuckarti (cf. egg development time; Taube \& Nauwerck 1967; Herzig 1983).

Wintering in diapause for $M$. leuckarti and $T$. oithonoides as copepodid stages IV-V, usually takes place in the sediments. Alternatively, a small fraction of some Norwegian $T$. oithonoides populations, but not $M$. leuckarti, used the deep-water plankton as an "active diapause" site (Næss et al. 1993). T. oithonoides diapaused for 5 months, whereas M. leuckarti diapaused for 7 months in Lake Gjerstadvann. The less intense and shorter diapause in $T$. oithonoides combined with its tendency to overwinter in the deep-water plankton in some neighbouring sites, supports the above observation that diapause in this species is less intense than in $M$. leuckarti.

The intensity of diapause (torpidity) is found to vary considerably in time and space within and between species (Elgmork 1996). Diapause is deep and prolonged in some dormancy sites, while in others it is less pronounced and lasts for a shorter period. M. leuckarti and T. oithonoides in Lake Gjerstadvann showed a low degree of torpidity, comparable to an earlier observation of M. leuckarti (Elgmork \& Nilssen 1978). No data seems to exist on the intensity of diapause in $T$. oithonoides. Elgmork (1996) furthermore suggested that the depth of torpidity during winter seemed to be correlated with an induction early in the year, and with instar development. In M. leuckarti, he (Elgmork 1996) found that cop V had shorter and less deep torpidity than cop IV.

The reproductive patterns of the two species, including clutch size, differed conspicuously. In Lake Gjerstadvann, both M. leuckarti and T. oithonoides produced comparable egg numbers to eutrophic lakes, both in Norway and other parts of Europe (Nilssen \& Wærvågen 2000), which suggests that even in eutrophic lakes, cyclopoid copepods might suffer from food scarcity. Clutch size usually decreased throughout the reproductive period, being more pronounced in the predation-vulnerable species $M$. leuckarti than $T$. oithonoides, with clutch sizes between 20-40 and 10-16, respectively.

The less abundant species Cyclops abyssorum was recorded during winter as advanced copepodids and a few adults. The scarcity of this large-sized cyclopoid (total body size 1.9-2.2 $\mathrm{mm}$ for adult females) in Lake Gjerstadvann could be due to a combination of low $\mathrm{pH}$, fish predation and competition with the other hypolimnetic species, C. scutifer (Brekke 1995). Its appearance 
in the plankton during winter, and the fact that it has never been recorded in the sediments here or in neighbouring lakes, probably indicate that $C$. abyssorum is perennally planktonic in Lake Gjerstadvann. This omnivorous species, dominating coastal rock-pools in the area, was also registered in the hypolimnion in a few lakes situated below the upper postglacial marine limit, but neither there exhibiting diapause in the sediment (Nilssen \& Wærvågen 2003).

\section{CONCLUSION}

The studied copepods in the oligotrophic Lake Gjerstadvann form the most common pelagic species in the western part of the Eurasian boreal region. E. gracilis inhabited the whole water column of Lake Gjerstadvann, but reproduced mainly in the epilimnion. A significant positive correlation was observed between temperature and developmental time during the spring and early summer generation of $E$. gracilis, suggesting that food availability was less important during this period of temporary food saturation. Developmental time of the omnivorous E. gracilis showed consistently longer generation times compared with laboratory animals, which was probably related to limited food availability.

The perennial C. scutifer displayed a one-year life cycle with co-existing late winter copepodids ("active diapause") and nauplii, and such splitting of the winter population was probably a response to low fish predation combined with synchronising of the life cycle for utilising early summer food. The rate of epilimnetic summer development for $M$. leuckarti was noticeably slower in Lake Gjerstadvann compared with laboratory animals, in contrast to E. gracilis where the difference was negligible. This indicated that sub-optimal food conditions existed for a carnivouous cyclopoid copepod such as M. leuckarti in Lake Gjerstadvann. The reason why ovigerous females of $M$. leuckarti migrated from the pelagial into the shallow littoral areas at specific times of the year was probably to utilize detritus and cladocerans as food items, and profit from much higher littoral temperatures offering more rapid development of the eggs and a possibility to produce more eggs at shorter time intervals. Habitat selection of diapausing M. leuckarti may also be influenced by potential prey availability in that specific site, since important prey species distribute their resting stages in the littoral as well.

M. leuckarti and T. oithonoides exhibited late instar winter diapause for several months in the shallow littoral and deepest parts of the lake, respectively, and both species showed a low degree of torpidity. Interannual variations in sediment densities of diapausing populations of T. oithonoides were conspicuous, and could be due to the fluctuating acidification or other chemical variations in the epilimnion of the lake during the most vulnerable ontogenetical stages, eggs and nauplii. $C$. scutifer, T. oithonoides, and C. abyssorum were proba- bly all negatively affected by the acidified waters in Lake Gjerstadvann. T. oithonoides was probably the most acid-vulnerable of the species recorded in Lake Gjerstadvann, and probably close to its physiological $\mathrm{pH}$-tolerance. These findings underscore the importance of sampling several sub-systems, especially the sediment and littoral regions, in life history studies of pelagic copepods.

\section{ACKNOWLEDGEMENTS}

We are most grateful to Frode Kroglund, Arne Linløkken, Steinar Sandøy, Anne Skov, and Arne Vethe for helpful field cooperation and valuable discussions, to Dag Olav Andersen and Odd K. Skogheim for help with the chemical analyses, and to Olav Smestad in Gjerstad Local Community for arranging accommodation and practical help. We are further thankful to Ian Watering and Robert Wilson for proofreading the manuscript, and to Gro Lindberg and Silje Ganger for digitalising the figures. Finally, we are thankful to the two anonymous referees for their insightful comments that clarified the objectives and aims of the paper.

\section{REFERENCES}

Alimov, A.F., V.V. Bouillion, N.P. Finogenova, M.B. Ivanova, N.K. Kuzmitskaja, V.N. Nikulina, N.G. Ozeretskovskaja \& T.V. Zharova. 1972. Biological productivity of lakes Krivoe and Krugloe. In: Kajak, Z. \& A. Hillbricht-Ilkowska (Eds), Productivity problems of freshwaters. PWV, Warszawa: 39-56.

Allan, J.D. 1976. Life history patterns in zooplankton. Am. Nat., 110: 165-180.

Alekseev, V.R., B.T. De Stasio \& J.J. Gilbert (Eds). 2007. Diapause in aquatic invertebrates. Monogr. Biol. 84. Springer-Verlag: $257 \mathrm{pp}$.

Axelson, J. 1961. On the dimorphism in Cyclops scutifer (Sars). Rep. Inst. Freshwat. Res. Drottningholm, 42: 169182.

Berger, I. \& G. Maier. 2001. The mating and reproductive biology of the freshwater planktonic copepod Eudiaptomus gracilis. Freshwat. Biol., 46: 787-794.

Bertilsson, J., B. Bērziņš \& B. Pejler. 1995. Occurrence of limnic micro-crustaceans in relation to temperature and oxygen. Hydrobiologia, 299: 163-167.

Bohonak, A.J., M.D. Holland, B. Santer, M. Zeller, C.M. Kearns \& N.G. Hairston jr. 2006. The population genetic consequences of diapause in Eudiaptomus copepods. Arch. Hydrobiol., 167: 183-202.

Brabrand, Å., B. Faafeng \& J.P. Nilssen. 1987. Pelagic predators and interfering algae: Stabilizing factors in eutrophic lakes. Arch. Hydrobiol., 110: 533-552.

Brandl, Z. \& C.H. Fernando. 1979. The impact of predation by the copepod Mesocyclops edax (Forbes) on zooplankton in three lakes in Ontario, Canada. Can. J. Zool., 57: 940-942.

Brekke, E. 1995. Predation avoidance in zooplankton: General overview and a field study on two freshwater cyclopoid copepods. Thesis, Univ. Bergen: 48 pp.

Chapman, A. 1969. The bionomics of Diaptomus gracilis Sars (Copepoda: Calanoida) in Loch Lomond, Scotland. $J$. Anim. Ecol., 38: 257-284.

Conover, R.J. 1968. Zooplankton - life in a nutritionally dilute environment. Amer. Zool., 8: 107-118.

Czeczuga, B. 1959. Oviposition of Eudiaptomus gracilis G.O. Sars and E. graciloides Lilljeborg (Diaptomidae, Crusta- 
cea) in relation to season and trophic level of lakes. Bull. Acad. Pol. Sci., 7(6): 227-230.

Czeczuga, B. 1960. Changes in fertility of some representatives of the zooplankton. I. Crustacea from the Rajgrodzkie lakes. Pol. Arch. Hydrobiol., 7: 61-91. (In Polish, summary in English).

Demmo, R. 1985. En undersøkelse av zooplanktonsamfunnene $i$ Bosvikkilen. En limnisk og en marin lokalitet ved Risør $i$ Aust-Agder. Thesis, Univ. Oslo: 202 pp. (Mimeogr. in Norwegian).

Dussart, B.H. \& D. Defaye. 2001. Introduction to the Copepoda. In: Dumont, H.J. (Ed.), Guides to the Identification of the Macroinvertebrates of the Continental Waters of the World. 16. Backhuys, Leiden: 344 pp.

Eckstein, H. 1964. Untersuchungen über den Einfluss der Rheinwasser auf die Limnologie des Schluchsees. Arch. Hydrobiol./Suppl., 28: 47-182.

Einsle, U. 1964. Das Crustaceenplankton des Mindelsees. Beitr. naturk. Forsch. SW-Deutschl., 23: 53-70.

Einsle, U. 1975. Revision de Gattung Cyclops s.str. speziell der abyssorum-Gruppe. Mem. Ist. ital. Idrobiol., 32: 57219.

Elgmork, K. 1958. On the phenology of Mesocyclops oithonoides (G.O. Sars). Verh. int. Ver. Limnol., 13: 778-784.

Elgmork, K. 1959. The seasonal occurence of Cyclops strenuus strenuus. Folia Limnol. Scand., 11:1-196.

Elgmork, K. 1962. A bottom resting stage in the planktonic freshwater copepod Cyclops scutifer SARS. Oikos, 13: 306-310.

Elgmork, K. 1964. Dynamics of zooplankton communities in some small inundated ponds. Folia Limnol. Scand., 12: 183.

Elgmork, K. 1965. A triennial copepod (Crustacea) in the temperate zone. Nature, 205: 413.

Elgmork, K. 1967. Ecological aspects of diapause in copepods. Proc Symp. Crustacea. Part III: 947-954.

Elgmork, K. 1985. Prolonged life cycle in the planktonic copepod Cyclops scutifer SARS. Verh. int. Ver. Limnol., 22: 3154-3158.

Elgmork, K. 1996. Variation in torpidity of diapause in freshwater cyclopoid copepods. Hydrobiologia, 320: 63-70.

Elgmork, K. 2004. Life cycles of the freshwater, planktonic copepod Cyclops scutifer SARS on a north-south gradient in North America. Hydrobiologia, 529: 37-48.

Elgmork, K. 2006. A monograph of life history strategies of the freshwater, planktonic copepod Cyclops scutifer G.O. SARS 1863. Arch. Hydrobiol./Suppl., 151: 301-351.

Elgmork, K. \& G. Halvorsen. 1998. Intraspecific morphological variation in a freshwater copepod (Crustacea) in relation to geographic distribution and environment. Can. J. Zool., 76: 751-762.

Elgmork, K. \& A. Langeland. 1980. Cyclops scutifer - oneand two-year life cycles with diapause in the meromictic lake Blankvatn. Arch. Hydrobiol., 88: 178-201.

Elgmork, K. \& J.P. Nilssen. 1978. Equivalence of copepod and insect diapause. Verh. int. Ver. Limnol., 20: 25112517.

Elgmork, K., J.P. Nilssen, T. Broch \& R. Øvrevik. 1978. Life cycle strategies in neighbouring populations of the copepod Cyclops scuifer Sars. Verh. int. Ver. Limnol., 20: 2518-2523.

Elster, H.J. 1954. Über die Populationsdynamik von Eudiaptomus gracilis Sars und Heterocope borealis Fischer im Bodensee-Obersee. Arch. Hydrobiol./Suppl., 20: 546-614.

Fjerdingstad, E. \& J.P. Nilssen. 1982. Bacteriological and hydrological studies on acidic lakes in Southern Norway. Arch.Hydrobiol./Suppl., 64: 443-483.

Flößner, D. 1972. Krebstiere, Crustacea; Kiemen- und Blattfüßer, Branchiopoda; Fischläuse, Branchiura. Die Tierwelt Deutschlands. 60 Teil. VEB Gustav Fischer Verlag, Jena, $501 \mathrm{pp}$.
Gieysztor, M. 1960. On the thermal conditions of the littoral zone of lakes. Pol. Arch. Hydrobiol., 7: 171-193.

Halvorsen, G. \& K. Elgmork. 1976. Vertical distribution and seasonal cycle of Cyclops scutifer Sars (Crustacea, Copepoda) in two oligotrophic lakes in southern Norway. Norw. J. Zool., 24: 143-160.

Hansen, A.-M. \& B. Santer. 1995. The influence of food resources on the development, survival and reproduction of the two cyclopoid copepods: Cyclops vicinus and Mesocyclops leuckarti. J. Plankton Res., 17: 631-646.

Herzig, A. 1983. The ecological significance of the relationship between temperature and duration of embryotic development in planktonic freshwater copepods. Hydrobiologia, 100: 65-91.

Herzig, A. 1984. Temperature and life cycle strategies of Diaphanosoma brachyurum: An experimental study on development, growth, and survival. Arch. Hydrobiol., 101: 143-178.

Hessen, D.O. \& L. Tranvik (Eds). 1998. Aquatic humic substances, ecology and biochemistry. Ecological Studies 133, Springer-Verlag: $346 \mathrm{pp}$.

Hesthagen, T., H.M. Berger, A.K.L. Schartau, T. Nøst, R. Saksgård \& L. Fløystad. 2001. Low success rate in re-establishing European perch in some highly acidified lakes in southernmost Norway. Water Air Soil Pollut., 130: 1361-1366.

Hindar, A., F. Kroglund, J.P. Nilssen, S. Sandøy, A. Skov, O. Smestad \& S.B. Wærvågen. 1984. Elvedata fra Gjerstad, Aust-Agder. En vannkjemisk datarapport. Rep. Norw. Liming Project, 15-1984: 1-47. (Mimeogr. in Norwegian).

Hobæk, A. \& G.G. Raddum. 1980. Zooplankton communities in acidified lakes in South Norway. SNSF-project, IR, 75/80: 1-132.

Hofman, W. 1979. Characteristics of synoptic populations of Eudiaptomus gracilis (Sars) and E. graciloides (Lilljeborg) in three lakes of different trophic levels. Arch. Hydrobiol., 86: 1-12.

Hopp, U., G. Maier \& R. Bleher. 1997. Reproduction and adult longevity of five species of planktonic cyclopoid copepods reared on different diets: a comparative study. Freshwat. Biol., 38: 289-300.

Illies, J. (Ed). 1978. Limnofauna Europaea (ed. 2). Gustav Fischer-Verlag. $532 \mathrm{pp}$.

Ivanova, M.B. 1961. Life cycle of Diaptomus gracilis Sars in humified lakes. Dokl. Akad. Nauk SSSR, 139: 1231-1234. (In Russian).

Kantona, S.K. 1975. Copulation in the copepod Eurytemora affinis (Poppe 1880). Crustaceana, 28: 89-100.

Keskitalo, J. \& P. Eloranta. (Eds). 1999. Limnology of humic waters. Backhuys Publishers: 284 pp.

Kiefer, F. 1978. Freilebende Copepoda. Die Binnengewässer, 26/2:1-343

Kleiven, E., D. Matzow, A. Linløkken \& A. Vethe. 1990. Regionale fiskeundersøkjingar $i$ Gjerstadvassdraget. DNnotat, 8/1990: 1-52 (In Norwegian).

Krylov, P.I., V.R. Alekseev \& O.A. Frenkel. 1996. Feeding and digestive activity of cyclopoid copepods in active diapause. Hydrobiologia, 320: 71-79.

Kutzne, H. 1938. Limnologische Untersuchen über das Crustaceenplankton des Schleinsees und zweier Kleingewässer. Int. Revue ges. Hydrobiol., 37: 164-233.

Larsen, D.A. 1982. Populasjonsdynamikk til zooplankton $i$ Fievann, et mixotroft kystvann i Aust-Agder, med spesiell vekt på konkurranse og predasjon som regulerende faktorer. Thesis, Univ. Oslo: 166 pp. (Mimeogr. in Norwegian).

Larsson, P. 1978. The life cycle dynamics and production of zooplankton in Øvre Heimdalsvann. Holarct. ecol., 1: $162-218$.

Lindström, T. 1952. Sur l'ecologie du zooplankton Crustacé. Rep. Inst. Freshwat. Res. Drottningholm, 33: 70-165. 
Lindström, T. 1958. Observations sur les cycles annuels de planctons crustacé. Dualisme des populations Copepodes Repercussion de années froides - Differences entre des lacs. Rep. Inst. Freshwat. Res. Drottningholm, 39: 99-145.

Linløkken, A. 1985. Populasjonsbiologi hos aure, sik, røye og abbor $i$ det forsurningstrua Gjerstadvann. Thesis, Univ. Oslo: 100 pp. (Mimeogr. in Norwegian).

Linløkken, A. 1988. Vertical distribution of brown trout (Salmo trutta) and perch (Perca fluviatilis) in an acidified lake. Water Air Soil Pollut., 40: 203-213.

Lydersen, E. 1998. Humus and acidification. In: Hessen, D.O. \& L. Tranvik (Eds), Aquatic humic substances, ecology and biochemistry. Ecological Studies 133, Springer-Verlag: 63-92.

Maier, G. 1989. The effect of temperature on the development times of eggs, naupliar and copepodid stages of five species of cyclopoid copepods. Hydrobiologia, 184: 79-88.

Maier, G. 1990. Coexistence of the predatory cyclopoids Acanthocyclops robustus (Sars) and Mesocyclops leuckarti (Claus) in a small eutrophic lake. Hydrobiologia, 198: 185-203.

Maier, G. \& R. Buchholz. 1996. Zooplankton communities of gravel pits in relation to trophy, dredging activity and macrophyte growth. Limnologica (Berl.), 26: 353-360.

Mittelholzer, E. 1970. Populationsdynamik und Produktion des Zooplanktons im Greifensee und im Vierwaldstättersee. Schweiz. Z. Hydrol., 32: 90-149.

Molot, L. \& P.J. Dillon. 1996. Storage of terrestrial carbon in boreal lake sediments and evasion to the atmosphere. Global Biogeochem. Cyc., 10: 483-492.

Monakov, A.V. 1972. Review of studies on feeding of aquatic invertebrates conducted at the Institute of Biology of inland waters, Academy of Sciences, USSR. J. Fish. Res. Board Can., 29: 363-383.

Monakov, A.V. \& Y.I. Sorokin. 1959. Experimental studies of the carnivorous feeding of Cyclopoida by means of an isotop method. Rep. Acad. Sci. USSR, 125: 201-204 (In Russian).

Morling, G. \& B. Pejler. 1990. Acidification and zooplankton development in some West-Swedish lakes 1966-1983. Limnologica (Berl.), 20: 307-318.

Munro, I.G. 1974. The effect of temperature on the development of egg, naupliar and copepodite stages of two species of copepods, Cyclops vicinus Uljanin and Eudiaptomus gracilis Sars. Oecologia (Berl.), 16: 355-367.

Næss, T. 1985. En undersøkelse av zooplanktonsamfunnene $i$ Vormelitjenn og Søndeledpollen, en limnisk og marin lokalitet ved Søndeled $i$ Aust-Agder. Thesis, Univ. Oslo: 226 pp. (Mimeogr. in Norwegian).

Næss, T. \& J.P. Nilssen. 1991. Life cycle dynamics of a Cyclops strenuus (Crustacea, Copepoda) population with unusual diapause and reproductive characteristics. Arch. Hydrobiol., 122: 323-334.

Næss, T., J.P. Nilssen \& R. Demmo. 1993. Individual lake characteristics modify the life cycles and diapause habitat of two neighbouring populations of the cyclopoid copepod Thermocyclops oithonoides. Can. J. Zool., 71: 1663-1672.

Nilssen, J.P. 1977. Cryptic predation and the demographic strategy of two limnetic cyclopoid copepods. Mem. Ist. ital. Idrobiol., 24: 187-195.

Nilssen, J.P. 1978. On the evolution of life histories of limnetic cyclopoid copepods. Mem. Ist. ital. Idrobiol., 36: 193-214.

Nilssen, J.P. 1980a. When and how to reproduce: A dilemma for limnetic cyclopoid copepods. In: W.C. Kerfoot, (Ed), Evolution and ecology of zooplankton communities. Univ.Press New England, Hanover: 418-426.

Nilssen, J.P. 1980b. Acidification of a small watershed in southern Norway and some characteristics of acidic aquatic environments. Int. Revue ges. Hydrobiol., 65: 177207.
Nilssen, J.P. 1982. La détection de l'acidification des lacs et de ses causes. Eau du Quebec, 15: 335-341.

Nilssen, J.P. \& K. Elgmork. 1977. Cyclops abyssorum - life cycle dynamics and habitat selection. Mem. Ist. ital. Idrobiol., 34: 197-238.

Nilssen, J.P. \& S.B. Wærvågen. 2000. Superficial ecosystem similarities vs autecological stripping: The "twin species" Mesocyclops leuckarti (Claus) and Thermocyclops oithonoides (Sars) - seasonal habitat utilisation and life history traits. J. Limnol., 59: 79-102.

Nilssen, J.P. \& S.B. Wærvågen. 2001. Kjemisk og biologisk "recovery" av forsurede innsjøer $i$ Aust-Agder. Kakede vann og referansevann i 1999 og 2000. Fylkesmannen i Aust-Agder, Rapport nr. 2 - 2001: 1-80 (Mimeogr. in Norwegian)

Nilssen, J.P. \& S.B. Wærvågen. 2003. Ecological distribution of pelagic copepods and species relationship to acidification, liming and natural recovery in a boreal area. $J$. Limnol., 62: 97-114.

Nyberg, J. 1981. Zooplanktonsamfunnet i Borrevannet, Vestfold, med spesiell vekt på livshistoriene til Cyclops strenuus, Mesocyclops leuckarti og Eurytemora velox. Thesis, Univ. Oslo: 118pp. (Mimeogr. in Norwegian).

Papinska, K. 1985. Carnivorous and detrivorous feeding of Mesocyclops leuckarti Claus (Cyclopoida, Copepoda). Hydrobiologia, 120: 249-257.

Ponyi, J.E. \& N.P. Zánkai. 1982. Population dynamics, biomass and biomass production of Eudiaptomus gracilis (G.O. Sars) in two water areas of differing trophic state of Lake Balaton (Hungary). Acta hydrochim. hydrobiol., 10: 597-610.

Ponyi, J.E., J.N. Horvath \& N.P. Zánkai. 1975. Investigations on planktonic Crustacea in Lake Balaton VI. Quantitative changes in the Eudiaptomus gracilis population at various regions of Lake Balaton. Ann. Biol. Tihany, 42: 203-218.

Romanovsky, Y.E. 1985. Food limitation and life-history strategies in cladoceran crustaceans. Arch. Hydrobiol. Beih./Ergeb. Limnol., 21: 363-372.

Ruttner-Kolisko, A. 1972. Rotatoria. Das zooplankton die Binnengewässer I: 99-234.

Rylov, W.M. 1963. Freshwater Cyclopoida. Fauna of the USSR. Crustacea. III (3). Israel progr. for scient. trans.: $318 \mathrm{pp}$.

Sandøy, S. 1984. Zooplanktonsamfunnet $i$ to forsura vatn $i$ Gjerstad i Aust-Agder. Virkning av biotiske og abiotiske faktorar på livssyklus og populasjonstetthet. Thesis, Univ. Oslo: 247 pp. (Mimeogr. in Norwegian).

Sandøy, S. \& J.P. Nilssen. 1987a. Life cycle dynamics and vertical distribution of Heterocope saliens (LILLJ.) in two anthropogenic acidic lakes in southern Norway. Arch. Hydrobiol., 110: 83-99.

Sandøy, S. \& J.P. Nilssen 1987b. Cyclopoid copepods in marginal habitats: Abiotic control of population densities in anthropogenic acidic lakes. Arch.Hydrobiol. Suppl., 76: 236-255.

Sarvala, J. 1979. Benthic resting periods of pelagic cyclopoids in an oligotrophic lake. Holarc. Ecol., 2: 88-100.

Schindler, D.W. 1969. Two useful devices for vertical plankton and water sampling. J. Fish. Res. Board Can., 26: 1948-1955.

Schindler, D.W. 1998. A dim future for boreal waters and landscapes. BioSciences, 48: 157-164.

Skogheim, O.K. 1979. Beskrivelse av en sedimenthenter konstruert for prøvetakning av korte sedimentkjerner. Rapport fra Årungenprosjektet 1979/2: 1-7 (In Norwegian, Abstract in English).

Skov, A. 1985. Livssyklus og tetthetsvariasjoner til zooplankton i et skogstjern, Store Finnetjenn, Gjerstad, Aust-Agder 1980-1982. Thesis, Univ. Oslo: 131 pp. (Mimeogr. in Norwegian). 
Smyly, W.J.P. 1961. The life cycle of the freshwater copepod Cyclops leuckarti in Esthwaite Water. J. Anim. Ecol., 30: 153-171.

Smyly, W.J.P. 1968. Observations on the planktonic and profundal Crustacea of the lakes of the English Lake District. J. Anim. Ecol., 37: 693-708.

Smyly, W.J.P. 1970. Observations on rate of development, longevity and fecundity of Acanthocyclops viridis (Jurne) (Copepoda, Cyclopoida) in relation to type of prey. Crustaceana, 18: 21-36.

Smyly, W.J.P. 1974. The effects of temperature on the development time of the eggs of three freshwater cyclopoid copepods from the English Lake District. Crustaceana, 27: 278-284.

Stebler, R. 1979. Das pelagische Crustaceenplankton des Bielersees: Abundanzdynamik, Produktion and Sukzession. Schweiz. Z. Hydrol., 41: 1-37.

Stenson, J.A.E. 1979. Predator-prey relations between fish and invertebrate prey in some forest lakes. Rep. Inst. Freshwat. Res. Drottningholm, 58: 166-183.

Svensson, J.-E. 1996. Predation on females and males of a freshwater copepod. Ph.D. Thesis, Univ. Gothenburg.

Taube, I. \& A. Neuwerck. 1967. Zur Populationsdynamik von Cyclops scutifer Sars. I. Die Temperaturabhängigkeit der Embryonalentwicklung von Cyclops scutifer Sars im Ver- gleich zu Mesocyclops leuckarti (Claus). Rep. Inst. Freshwat. Res. Drottningholm, 47: 76-86.

Twombly, S. 1995. Phenotypic variation in metamorphosis in four species of freshwater copepods. Freshwat. Biol., 34: 29-38.

Vethe, A. 1988. Sesongvariasjon $i$ habitatfordeling og noeringsval til abbor og aure $i$ eit forsuringstrua vatn $i$ Sør-Noreg. Thesis, Univ. Oslo: 62 pp. (Mimeogr. in Norwegian).

Vijverberg, J. 1980. Effect of temperature in laboratory studies on development and growth of Cladocera and Copepoda from Tjeukemeer, The Netherlands. Freshwat. Biol., 10: 317-340.

Wærvågen, S.B. 1985. En limnologisk studie av Gjerstadvann i Aust-Agder, med spesiell vekt på zooplanktonsamfunnets livshistorier og populasjonsdynamikk. Thesis, Univ. Oslo: 177 pp. (Mimeogr. in Norwegian).

Winfield, I.J. \& C.R. Townsend. 1983. The cost of copepod reproduction: increased susceptibility to fish predation. Oecologia (Berl.), 59: 406-411.

Zaret, T.M. 1980. Predation and freshwater communities. Yale Univ. Press: $187 \mathrm{pp}$.

Zánkai, P.N. 1978. The duration of development of Eudiaptomus gracilis (G.O. Sars) (Copepoda) in Lake Balaton. Acta Biol. Debrecina, 15: 183-198. 